\title{
Organocatalytic Vinyl and Friedel-Crafts Alkylations with Trifluoroborate Salts
}

\author{
Sandra Lee and David W. C. MacMillan* \\ Merck Center for Catalysis at Princeton University, Princeton, New Jersey 08544 \\ Division of Chemistry, California Institute of Technology, Pasadena, California 91125
}

\section{Supporting Information}

General Information. Commercial reagents were purified prior to use following the guidelines of Perrin and Armarego. ${ }^{1}$ All solvents were purified according to the method of Grubbs. ${ }^{2}$ Organic solutions were concentrated under reduced pressure on a Büchi rotary evaporator using an ice-water bath for volatile compounds. Potassium tri(fluoro)borate salts were synthesized from commercially available boronic acids or esters using a modified Molander procedure. ${ }^{3}$ Chromatographic purification of products was accomplished using force-flow chromatography on Silicycle silica gel according to the method of Still ${ }^{4}$ and where noted, Iatrobeads 6RS-8060 was used in place of silica gel. Thin-layer chromatography (TLC) was performed on Silicycle $250 \mu \mathrm{m}$ silica gel plates. Visualization of the developed chromatogram was performed by fluorescence quenching and anisaldehyde stain.

${ }^{1} \mathrm{H}$ and ${ }^{13} \mathrm{C}$ NMR spectra were recorded on a Varian Mercury $300(300 \mathrm{MHz}$ or 75 $\mathrm{MHz})$, Mercury 400 (400 MHz or $100 \mathrm{MHz})$, or an Inova $500(500 \mathrm{MHz}$ and $125 \mathrm{MHz})$ as noted, and are internally referenced to residual protio solvent signals (note: $\mathrm{CDCl}_{3}$

(1) Perrin, D. D.; Armarego, W. L. F. Purification of Laboratory Chemicals; $3^{\text {rd }}$ ed., Pergamon Press, Oxford, 1988.

(2) Pangborn, A. B.; Giardello, M. A.; Grubbs, R. H.; Rosen, R. K.; Timmers, F. J. Organometallics, 1996, $15,1518$.

(3) (a) Molander, G. A.; Ito, T. Org. Lett. 2001, 3, 393. (b) Molander, G. A.; Biolatto, B. Org. Lett. 2002, 4, 1867. Note: The cited procedures were found to be more efficient when reaction slurries were sonicated.

(4) Still, W. C.; Kahn, M.; Mitra, A. J. J. Org. Chem. 1978, 43, 2923. 
referenced at $\delta$ 7.24). Data for ${ }^{1} \mathrm{H}$ NMR are reported as follows: chemical shift ( $\left.\delta \mathrm{ppm}\right)$, multiplicity ( $\mathrm{s}=$ singlet, $\mathrm{d}=$ doublet, $\mathrm{t}=$ triplet, $\mathrm{q}=$ quartet, $\mathrm{m}=$ multiplet $)$, integration, coupling constant $(\mathrm{Hz})$ and assignment. Data for ${ }^{13} \mathrm{C} N \mathrm{NMR}$ are reported in terms of chemical shift. IR spectra were recorded on a Perkin Elmer Paragon 1000 spectrometer and are reported in terms of frequency of absorption $\left(\mathrm{cm}^{-1}\right)$. Mass spectra were obtained from the California Institute of Technology Mass Spectral Facility and the Princeton Mass Spectroscopy Facility. Gas liquid chromatography (GLC) was performed on Hewlett-Packard 6850 and 6890 Series gas chromatographs equipped with split-mode capillary injection system and flame ionization detectors using Bodman Chiraldex $\Gamma$-TA (30 m x $0.25 \mathrm{~mm}$ ) column. Supercritical fluid chromatography (SFC) was performed on a Berger Minigram equipped with a diode array UV detector $(\lambda=214-258 \mathrm{~nm})$ using a chiral column $(25 \mathrm{~cm})$ and guard column $(5 \mathrm{~cm})$ as noted for each compound.

General procedure: To a plastic vial (Wheaton HDPE) is added HF (48 wt \%, $1.0 \mathrm{eq})$ followed by 1,2-dimethoxyethane (DME) (1M, relative to aldehyde) and a magnetic stir bar. The catalyst and acid co-catalyst are charged to the vial with the addition of $\quad(2 S, 5 S)$-2-tert-butyl-5-((1-benzyl-1H-indol-3-yl)methyl)-3methylimidazolidin-4-one ( $0.2 \mathrm{eq})$ and $\mathrm{HCl}(0.2 \mathrm{eq})$ and is then cooled to temperature (as noted). The reaction is started with the addition of the aldehyde (3.0 eq) to the DME solution immediately followed by the addition of the trifluoroborate salt (1.0 eq). The reaction is stirred at temperature and is often worked-up by an aqueous quench, which is then partitioned with dichloromethane, chloroform or ether, as noted. The combined organic layers are dried over $\mathrm{Na}_{2} \mathrm{SO}_{4}$ and concentrated in vacuo. The crude oil is then purified by column chromatography (conditions noted) to yield the desired product.

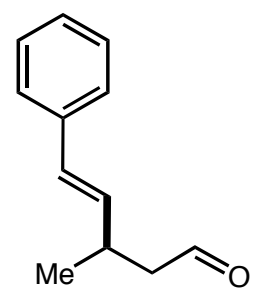


$(\boldsymbol{R}, \boldsymbol{E})$-3-methyl-5-phenylpent-4-enal (Table 2, entry 1). Prepared according to the general procedure using crotonaldehyde and potassium trans-styryltrifluoroborate. To a plastic vial is added HF (48 wt $\%, 7.00 \mathrm{mg}, 0.167 \mathrm{mmol})$ followed by DME $(500 \mu \mathrm{L})$ and a magnetic stir bar. The catalyst and acid co-catalyst are charged to the vial with the addition of $\quad(2 S, \quad 5 S)$-2-tert-butyl-5-((1-benzyl-1H-indol-3-yl)methyl)-3methylimidazolidin-4-one $(12.5 \mathrm{mg}, 0.033 \mathrm{mmol})$ and $\mathrm{HCl}(4 \mathrm{~N}$ in dioxane, $8.30 \mu \mathrm{L}$, $0.033 \mathrm{mmol})$ and is then cooled to $-20{ }^{\circ} \mathrm{C}$. Crotonaldehyde $(58.0 \mu \mathrm{L}, 0.50 \mathrm{mmol})$ is charged to the DME solution followed by the addition of potassium 2benzofuranyltrifluoroborate $(37.3 \mathrm{mg}, 0.167 \mathrm{mmol})$. The reaction is stirred at $-20{ }^{\circ} \mathrm{C}$ for 24 hours and quenched with $1 \mathrm{M} \mathrm{HCl}(1.0 \mathrm{~mL})$ and is stirred with chloroform $(1.5 \mathrm{~mL})$ for 30 minutes. The organic layer is extracted with $\mathrm{CH}_{2} \mathrm{Cl}_{2}(2 \times 2.0 \mathrm{~mL})$, dried over $\mathrm{Na}_{2} \mathrm{SO}_{4}$, filtered through celite (ether wash) and concentrated in vacuo. Purification by chromatography (silica gel, $20 \%$ ether in pentanes) yields the title compound as clear oil (27.9 mg, 96\% yield, 87\% ee). IR (film) 2962, 1718, 965.0, 747.0, 692.5 cm ${ }^{-1}$; ${ }^{1} \mathrm{H}$ NMR $\left(300 \mathrm{MHz}, \mathrm{CDCl}_{3}\right) \delta 9.76(\mathrm{t}, 1 \mathrm{H}, \mathrm{J}=2.1 \mathrm{~Hz}, \mathrm{CHO}), 7.34-7.19(\mathrm{~m}, 5 \mathrm{H}$, aryl H), 6.42 (dd, $1 \mathrm{H}, \mathrm{J}=0.6,15.9 \mathrm{~Hz}, \mathrm{CH}=\mathrm{CH}), 6.14(\mathrm{dd}, 1 \mathrm{H}, \mathrm{J}=7.5,15.9 \mathrm{~Hz}, \mathrm{CH}=\mathrm{CH}), 2.94(\mathrm{~m}, 1 \mathrm{H}$, $\left.\mathrm{CHCH}_{3}\right), 2.50\left(\mathrm{ddd}, 2 \mathrm{H}, \mathrm{J}=2.1,6.9,16.5 \mathrm{~Hz}, \mathrm{CH}_{2}\right), 1.16\left(\mathrm{~d}, 3 \mathrm{H}, \mathrm{CH}_{3}\right) ;{ }^{13} \mathrm{C} \mathrm{NMR}(75$ $\left.\mathrm{MHz}, \mathrm{CDCl}_{3}\right) \delta 202.33,134.16,129.32,128.76,127.50,126.33,50.60,32.08,20.65 ;$ HRMS (EI+) exact mass calculated for $[\mathrm{M}]^{+\bullet}\left(\mathrm{C}_{12} \mathrm{H}_{14} \mathrm{O}\right)$ requires $m / z$ 174.1045, found $\mathrm{m} / \mathrm{z}$ $174.1051 ;[\alpha]_{D}=-49.1\left(\mathrm{c}=0.45, \mathrm{CHCl}_{3}\right)$. The enantiomeric excess was determined on the alcohol product, which was prepared by a $\mathrm{NaBH}_{4}$ reduction, by SFC analysis using a Chiralcel OD-H column (5\% to $35 \%$ IPA, linear gradient, 100 bar, $35{ }^{\circ} \mathrm{C}$ oven, flow $=$ $4.0 \mathrm{~mL} / \mathrm{min}) ;(S)$ isomer $\mathrm{t}_{\mathrm{r}}=4.75 \mathrm{~min},(R)$ isomer $\mathrm{t}_{\mathrm{r}}=5.35 \mathrm{~min}$.

Determination of the absolute stereochemistry of $(R, E)-3-m e t h y l-5-$ phenylpent-4-enal by correlation to methyl [1-((E)-sytryl)ethyl]acetate. ${ }^{5}$ Aldehyde 4

(5) Hayashi, T.; Yamamoto, A.; Hagihara, T. J. Org. Chem. 1986, 51, $723\left(\right.$ reported $[\alpha]_{D}=-49.2\left(\mathrm{c}=1.3, \mathrm{CCl}_{4}\right)$ for a product that was $79 \%$ ee). 
(22.0 mg, $0.126 \mathrm{mmol}$ ) was subjected to oxidation ${ }^{6}$ using Oxone® $(77.6 \mathrm{mg}, 0.126$ $\mathrm{mmol})$ in DMF $(1.26 \mathrm{~mL})$ to quantitatively produce the corresponding acid $(24.0 \mathrm{mg}$, $0.126 \mathrm{mmol})$. Subsequently, the acid was esterified using TMS diazomethane (2M in hexane, $130 \mu \mathrm{L})$ in a solution of $25 \%$ methanol in benzene $(1.0 \mathrm{~mL})$ at room temperature. Purification was accomplished via chromatography (prep TLC, 20\% ether in pentanes) to yield $(R, E)$-methyl 3-methyl-5-phenylpent-4-enoate in 34\% isolated yield. ${ }^{1} \mathrm{H}$ NMR and ${ }^{13} \mathrm{C}$ NMR (500 MHz, $\mathrm{CCl}_{4}$ with TMS internal reference) spectral data matched literature values. ${ }^{4}{ }^{1} \mathrm{H}$ NMR $\left(400 \mathrm{MHz}, \mathrm{CDCl}_{3}\right) \delta$ 7.34-7.18 (m, 5H, aryl H), $6.38(\mathrm{~d}, 1 \mathrm{H}, \mathrm{J}=15.6$ $\mathrm{Hz}, \mathrm{CH}=\mathrm{CH}), 6.12$ (dd, 1H, J = 7.6, $15.9 \mathrm{~Hz}, \mathrm{CH}=\mathrm{CH}), 6.14(\mathrm{dd}, 1 \mathrm{H}, \mathrm{J}=7.5,16.0 \mathrm{~Hz}$, $\mathrm{CH}=\mathrm{CH}), 3.65$ (s, 3H, $\left.\mathrm{OCH}_{3}\right), 2.84$ (septet, 1H, J = 7.2 Hz, $\left.\mathbf{C H C H}_{2}\right), 2.39$ (ddd, 2H, J = 7.2, 14.4, 21.6 Hz, CH$) 1.13\left(\mathrm{~d}, 3 \mathrm{H}, \mathrm{J}=6.4 \mathrm{~Hz}, \mathrm{CH}_{3}\right) ;{ }^{13} \mathrm{C} \mathrm{NMR}\left(100 \mathrm{MHz}, \mathrm{CDCl}_{3}\right) \delta$ $173.1,134.4,129.1,128.7,127.4,126.3,51.74,41.73,34.22,20.42 ;[\alpha]_{D}=-57.8(\mathrm{c}=$ $\left.0.502, \mathrm{CCl}_{4}\right)$.

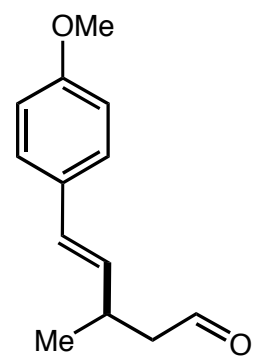

(R,E)-5-(4-methoxyphenyl)-3-methylpent-4-enal (Table 2, entry 2). Prepared according to the general procedure using crotonaldehyde and potassium trans-2-(4methoxyphenyl)trifluoroborate. To a plastic vial is added HF (48 wt\%, $3.5 \mathrm{mg}, 0.083$ mmol) followed by DME $(250 \mu \mathrm{L})$ and a magnetic stir bar. The catalyst and acid cocatalyst are charged to the vial with the addition of $(2 S, 5 S)$-2-tert-butyl-5-((1-benzyl-1Hindol-3-yl)methyl)-3-methylimidazolidin-4-one $(6.25 \mathrm{mg}, 0.017 \mathrm{mmol})$ and $\mathrm{HCl}(4 \mathrm{~N}$ in dioxane, $4.2 \mu \mathrm{L}, 0.017 \mathrm{mmol})$ and is then cooled to $-40{ }^{\circ} \mathrm{C}$. Crotonaldehyde $(21.0 \mu \mathrm{L}$, $0.25 \mathrm{mmol}$ ) is charged to the DME solution followed by the addition of potassium trans2-(4-methoxyphenyl)trifluoroborate $(20.0 \mathrm{mg}, 0.083 \mathrm{mmol})$. The reaction is stirred at -

(6) Travis, B. R.; Sivakumar, M.; Hollist, G. O.; Borhan, B. Org. Lett. 2003, 5, 1031. 
$40{ }^{\circ} \mathrm{C}$ for 20 hours and quenched with $1 \mathrm{M} \mathrm{HCl}(1.0 \mathrm{~mL})$ and is stirred with chloroform $(1.5 \mathrm{~mL})$ for 30 minutes. The organic layer is extracted with $\mathrm{CH}_{2} \mathrm{Cl}_{2}(2 \times 2.0 \mathrm{~mL})$, dried over $\mathrm{Na}_{2} \mathrm{SO}_{4}$, filtered through celite (ether wash) and concentrated in vacuo. Purification by chromatography (prep TLC, 10\% ether in pentanes) yields the title compound as clear oil (13.9 mg, 70\% yield, 88\% ee). IR (film) 2954, 1720, 1605, 1510, 1243, 1174, 1030, 964.8, 804.7 $\mathrm{cm}^{-1}$; ${ }^{1} \mathrm{H}$ NMR (300 MHz, $\mathrm{CDCl}_{3}$ ) $\delta 9.77(\mathrm{t}, 1 \mathrm{H}, \mathrm{J}=2.1 \mathrm{~Hz}, \mathrm{CHO}), 7.27(\mathrm{~d}$, $2 \mathrm{H}, \mathrm{J}=8.4 \mathrm{~Hz}$, aryl $\mathbf{H}), 6.84(\mathrm{~d}, 2 \mathrm{H}, \mathrm{J}=9.0 \mathrm{~Hz}$, aryl $\mathbf{H}), 6.36(\mathrm{~d}, 1 \mathrm{H}, \mathrm{J}=15.9 \mathrm{~Hz}$, $\mathrm{CH}=\mathrm{CH}), 6.01(\mathrm{dd}, 1 \mathrm{H}, \mathrm{J}=7.5,15.9 \mathrm{~Hz}, \mathrm{CH}=\mathrm{CH}), 3.80\left(\mathrm{~s}, 3 \mathrm{H}, \mathrm{OCH}_{3}\right), 2.93(\mathrm{~m}, 1 \mathrm{H}$, $\mathrm{CHCH}_{2}$ ), 2.50 (ddd, 2H, J = 2.1, 7.2, $\left.16.2 \mathrm{~Hz}, \mathrm{CH}_{2}\right), 1.17\left(\mathrm{~d}, 3 \mathrm{H}, \mathrm{J}=6.6 \mathrm{~Hz}, \mathrm{CH}_{3}\right) ;{ }^{13} \mathrm{C}$ NMR (75 MHz, $\left.\mathrm{CDCl}_{3}\right) \delta$ 202.54, 159.17, 132.01, 130.11, 128.68, 127.44, 114.15, 55.51, $50.73,32.11,20.79$; HRMS (EI+) exact mass calculated for $[\mathrm{M}]^{+\bullet}\left(\mathrm{C}_{13} \mathrm{H}_{16} \mathrm{O}_{2}\right)$ requires $\mathrm{m} / \mathrm{z}$ 204.1150, found $\mathrm{m} / \mathrm{z}, 204.1150 ;[\alpha]_{\mathrm{D}}=-44.0\left(\mathrm{c}=1.26, \mathrm{CHCl}_{3}\right)$. The enantiomeric excess was determined by SFC analysis using a Chiralpak AS-H column (5\% to $10 \% \mathrm{MeCN}$, linear gradient, $100 \mathrm{bar}, 35{ }^{\circ} \mathrm{C}$ oven, flow $\left.=4.0 \mathrm{~mL} / \mathrm{min}\right) ;(S)$ isomer $\mathrm{t}_{\mathrm{r}}=4.03 \mathrm{~min},(R)$ isomer $\mathrm{t}_{\mathrm{r}}=4.68 \mathrm{~min}$.

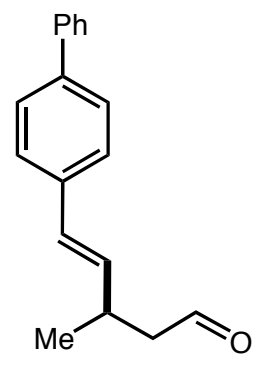

(R,E)-5-(4-biphenyl)-3-methylpent-4-enal (Table 2, entry 3). Prepared according to the general procedure using crotonaldehyde and potassium trans-2(biphenyl)trifluoroborate. To a plastic vial is added HF (48 wt $\%, 6.3 \mathrm{mg}, 0.15 \mathrm{mmol}$ ) followed by DME $(450 \mu \mathrm{L})$ and a magnetic stir bar. The catalyst and acid co-catalyst are charged to the vial with the addition of (2S, 5S)-2-tert-butyl-5-((1-benzyl-1H-indol-3yl)methyl)-3-methylimidazolidin-4-one $(11.3 \mathrm{mg}, 0.03 \mathrm{mmol})$ and $\mathrm{HCl}(4 \mathrm{~N}$ in dioxane, $7.5 \mu \mathrm{L}, 0.03 \mathrm{mmol})$ and is then cooled to $-40{ }^{\circ} \mathrm{C}$. Crotonaldehyde $(37.5 \mu \mathrm{L}, 0.45 \mathrm{mmol})$ is charged to the DME solution followed by the addition of potassium trans-2-(4- 
biphenyl)trifluoroborate $(42.9 \mathrm{mg}, 0.15 \mathrm{mmol})$. The reaction is stirred at $-40{ }^{\circ} \mathrm{C}$ for 24 hours and was directly subjected to purification by chromatography (Iatrobeads, 1\% acetone and 5\% ether in pentanes) to yield the title compound as light, yellow solid (20.6 mg, 91\% yield, 95\% ee). IR (film) 2924, 2854, 1724, 972.3, 761.7, $694.4 \mathrm{~cm}^{-1} ;{ }^{1} \mathrm{H}$ NMR $\left(500 \mathrm{MHz}, \mathrm{CDCl}_{3}\right) \delta 9.78(\mathrm{t}, 1 \mathrm{H}, \mathrm{J}=2.0 \mathrm{~Hz}, \mathrm{CHO}), 7.58-7.52(\mathrm{~m}, 4 \mathrm{H}$, aryl H), 7.43-7.39 (m, 4H, aryl H), 7.33-7.24 (m, 1H, aryl H), $6.44(\mathrm{~d}, 1 \mathrm{H}, \mathrm{J}=16.0 \mathrm{~Hz}, \mathrm{CH}=\mathrm{CH}), 6.19$ (dd, $1 \mathrm{H}, \mathrm{J}=7.5,16.0 \mathrm{~Hz}, \mathrm{CH}=\mathrm{CH}), 2.97\left(\right.$ septet, $\left.2 \mathrm{H}, \mathrm{J}=7.0 \mathrm{~Hz}, \mathrm{CHCH}_{2}\right), 2.52(\mathrm{ddd}, 2 \mathrm{H}, \mathrm{J}=$ 2.0, 7.0, $\left.16.5 \mathrm{~Hz}, \mathrm{CH}_{2}\right), 1.18\left(\mathrm{~d}, 3 \mathrm{H}, \mathrm{J}=7.0 \mathrm{~Hz}, \mathrm{CH}_{3}\right) ;{ }^{13} \mathrm{C} \mathrm{NMR}\left(125 \mathrm{MHz} \mathrm{CDCl}_{3}\right) \delta$ $202.21,140.95,140.31,136.41,134.34,128.99,128.93,127.46,127.12,126.77,50.65$, 32.15, 29.92, 20.67; HRMS (EI+) exact mass calculated for $[\mathrm{M}]^{+\bullet}\left(\mathrm{C}_{13} \mathrm{H}_{16} \mathrm{O}_{2}\right)$ requires $\mathrm{m} / z$ 250.1358, found $m / z, 250.1349 ;[\alpha]_{D}=-13.6\left(\mathrm{c}=1.29, \mathrm{CHCl}_{3}\right)$. The enantiomeric excess was determined by SFC analysis using a Chiralcel OJ-H column $(5 \%$ to $15 \% \mathrm{MeCN}$, $2 \% / \mathrm{min}$ gradient, $100 \mathrm{bar}, 35{ }^{\circ} \mathrm{C}$ oven, flow $\left.=4.0 \mathrm{~mL} / \mathrm{min}\right) ;(S)$ isomer $\mathrm{t}_{\mathrm{r}}=2.97 \mathrm{~min},(R)$ isomer $\mathrm{t}_{\mathrm{r}}=3.23 \mathrm{~min}$.

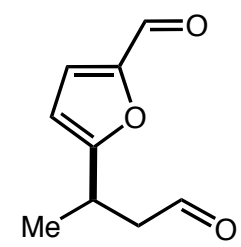

5-((R)-1-formylpropan-2-yl)furan-2-carbaldehyde (Table 2 , entry 4). Prepared according to the general procedure using crotonaldehyde and potassium 2-(5formylfuran-2-yl) trifluoroborate. To a plastic vial is added HF (48 wt\%, $3.5 \mathrm{mg}, 0.083$ mmol) followed by DME $(250 \mu \mathrm{L})$ and a magnetic stir bar. The catalyst and acid cocatalyst are charged to the vial with the addition of $(2 S, 5 S)$-2-tert-butyl-5-((1-benzyl-1Hindol-3-yl)methyl)-3-methylimidazolidin-4-one $(6.25 \mathrm{mg}, 0.017 \mathrm{mmol})$ and $\mathrm{HCl}(4 \mathrm{~N}$ in dioxane, $4.2 \mu \mathrm{L}, 0.017 \mathrm{mmol})$ and is then cooled to $-20{ }^{\circ} \mathrm{C}$. Crotonaldehyde $(21.0 \mu \mathrm{L}$, $0.25 \mathrm{mmol})$ is charged to the DME solution followed by the addition of potassium 2-(5formylfuran-2-yl) trifluoroborate $(20.0 \mathrm{mg}, 0.083 \mathrm{mmol})$. The reaction is stirred at -20 ${ }^{\circ} \mathrm{C}$ for 20 hours and quenched with $1 \mathrm{M} \mathrm{HCl}(1.0 \mathrm{~mL})$ and is stirred with ether $(1.5 \mathrm{~mL})$ 
for 30 minutes. The organic layer is extracted with ether $(2 \times 2.0 \mathrm{~mL})$, dried over $\mathrm{Na}_{2} \mathrm{SO}_{4}$, filtered through celite (ether wash) and concentrated in vacuo (ice-water bath). Purification by chromatography (silica gel, $10 \%$ ether in pentanes) yields the title compound as a clear, light yellow oil (11.7 mg, 85\% yield, 95\% ee). IR (film) 1719, 1670, 1513, $1020 \mathrm{~cm}^{-1} ;{ }^{1} \mathrm{H}$ NMR (300 MHz, $\mathrm{CDCl}_{3}$ ) $\delta 9.75$ (t, $1 \mathrm{H}, \mathrm{J}=1.5 \mathrm{~Hz}, \mathrm{CHO}$ ), $9.51(\mathrm{~s}, 1 \mathrm{H}$, furyl CHO), $7.17(\mathrm{~d}, 1 \mathrm{H}, \mathrm{J}=3.6 \mathrm{~Hz}$, aryl $\mathbf{H}), 6.30(\mathrm{dd}, 1 \mathrm{H}, \mathrm{J}=0.9,3.6$, aryl $\mathbf{H}), 3.53\left(\mathrm{~m}, 1 \mathrm{H}, \mathbf{C H C H}_{3}\right), 2.81\left(\mathrm{ddd}, 2 \mathrm{H}, \mathrm{J}=1.5,7.2,17.7 \mathrm{~Hz}, \mathbf{C H}_{2}\right), 1.35(\mathrm{~d}, 3 \mathrm{H}, \mathrm{J}=7.2$ $\left.\mathrm{Hz}, \mathrm{CH}_{3}\right) ;{ }^{13} \mathrm{C}$ NMR $\left(75 \mathrm{MHz}, \mathrm{CDCl}_{3}\right.$ ) $\delta 200.53,177.45,152.56,123.72,108.38,49.08$, 28.55, 19.07; HRMS (EI+) exact mass calculated for [ $\left.\mathrm{M}^{+*}\right]\left(\mathrm{C}_{9} \mathrm{H}_{10} \mathrm{O}_{3}\right)$ requires $\mathrm{m} / \mathrm{z}$ 166.0630, found $\mathrm{m} / \mathrm{z}$ 166.0629; $[\alpha]_{\mathrm{D}}=-1.09\left(\mathrm{c}=1.17, \mathrm{CHCl}_{3}\right)$. The enantiomeric excess was determined by SFC analysis using a Chiralpak AS-H column (5\% to $10 \% \mathrm{MeCN}$, linear gradient, $100 \mathrm{bar}, 35^{\circ} \mathrm{C}$ oven, flow $\left.=4.0 \mathrm{~mL} / \mathrm{min}\right) ;(S)$ isomer $\mathrm{t}_{\mathrm{r}}=2.73 \mathrm{~min},(R)$ isomer $\mathrm{t}_{\mathrm{r}}=3.63 \mathrm{~min}$.

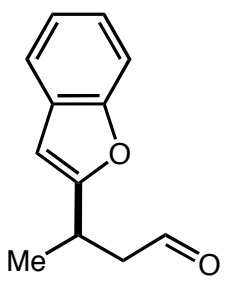

(R)-3-(benzofuran-2-yl)butanal (Table 2, entry 5). Prepared according to the general procedure using crotonaldehyde and potassium 2-benzofuranyltrifluoroborate. ${ }^{7}$ To a plastic vial is added HF ( $48 \mathrm{wt} \%, 6.25 \mathrm{mg}, 0.167 \mathrm{mmol}$ ) followed by DME ( $450 \mu \mathrm{L}$ ) and a magnetic stir bar. The catalyst and acid co-catalyst are charged to the vial with the addition of $\quad(2 S, \quad 5 S)$-2-tert-butyl-5-((1-benzyl-1H-indol-3-yl)methyl)-3methylimidazolidin-4-one $(11.3 \mathrm{mg}, 0.033 \mathrm{mmol})$ and $\mathrm{HCl}(4 \mathrm{~N}$ in dioxane, $7.50 \mu \mathrm{L}$, $0.033 \mathrm{mmol})$ and is then cooled to $-20{ }^{\circ} \mathrm{C}$. Crotonaldehyde $(37.3 \mu \mathrm{L}, 0.45 \mathrm{mmol})$ is charged to the DME solution followed by the addition of potassium 2benzofuranyltrifluoroborate $(33.6 \mathrm{mg}, 0.150 \mathrm{mmol})$. The reaction is stirred at $-20{ }^{\circ} \mathrm{C}$ for

(7) Murphy, J. M.; Tzschucke, C. C.; Hartwig, J. F. Org. Lett. 2007, 9, 757. 
23 hours and then flushed though a silica gel plug (wash with 30\% ether in pentanes). Concentration in vасио (ice-water bath) provided the title compound as clear oil (25.5 mg, 90\% yield, 97\% ee). IR (film) 1722, 1454, 1253, 1168, $750.6 \mathrm{~cm}^{-1} ;{ }^{1} \mathrm{H}$ NMR (300 $\left.\mathrm{MHz}, \mathrm{CDCl}_{3}\right) \delta 9.84$ (s, 1H, CHO), 7.54-7.43 (m, 2H, aryl H), 7.29-7.19 (m, 2H, aryl H), $6.45(\mathrm{t}, 1 \mathrm{H}, \mathrm{J}=0.9 \mathrm{~Hz}, 3$ '-benzofuran $\mathbf{H}), 3.61\left(\mathrm{~m}, 1 \mathrm{H}, \mathrm{CHCH}_{3}\right), 2.85(\mathrm{dd}, 2 \mathrm{H}, \mathrm{J}=1.80$, $\left.17.1 \mathrm{~Hz}, \mathrm{CH}_{2}\right), 1.45$ (d, 3H, J = 6.60 Hz, CH 3$\left.) ;{ }^{13} \mathrm{C} \mathrm{NMR} \mathrm{(75} \mathrm{MHz,} \mathrm{CDCl}_{3}\right) \delta 201.06$, 161.47, 154.81, 128.68, 123.81, 122.81, 120.75, 111.07, 101.58, 49.06, 28.38, 19.04; HRMS (EI+) exact mass calculated for $[\mathrm{M}]^{+\bullet}\left(\mathrm{C}_{12} \mathrm{H}_{12} \mathrm{O}_{2}\right)$ requires $\mathrm{m} / \mathrm{z} 188.0837$, found $\mathrm{m} / \mathrm{z}$ 188.0844; $[\alpha]_{D}=-17.1\left(\mathrm{c}=1.22, \mathrm{CHCl}_{3}\right)$. The enantiomeric excess was determined on the alcohol product, which was prepared by a $\mathrm{NaBH}_{4}$ reduction, by SFC analysis using a Chiralpak AS-H column (5\% to $50 \% \mathrm{MeOH}$, linear gradient, 100 bar, $35^{\circ} \mathrm{C}$ oven, flow = $4.0 \mathrm{~mL} / \mathrm{min}) ;(S)$ isomer $\mathrm{t}_{\mathrm{r}}=2.17 \mathrm{~min},(R)$ isomer $\mathrm{t}_{\mathrm{r}}=2.40 \mathrm{~min}$.

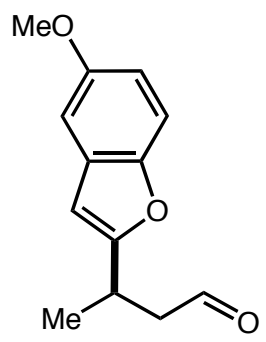

(R)-3-(5-methoxybenzofuran-2-yl)butanal (Table 2, entry 6). Prepared according to the general procedure using crotonaldehyde and potassium 2-(5methoxybenzofuranly)trifluoroborate. To a plastic vial is added HF (48 wt\%, $6.25 \mathrm{mg}$, $0.15 \mathrm{mmol})$ followed by DME $(450 \mu \mathrm{L})$ and a magnetic stir bar. The catalyst and acid co-catalyst are charged to the vial with the addition of $(2 S, 5 S)$-2-tert-butyl-5-((1-benzyl$1 H$-indol-3-yl)methyl)-3-methylimidazolidin-4-one (10.9 mg, $0.03 \mathrm{mmol})$ and $\mathrm{HCl}(4 \mathrm{~N}$ in dioxane, $7.5 \mu \mathrm{L}, 0.03 \mathrm{mmol})$ and is then cooled to $-20^{\circ} \mathrm{C}$. Crotonaldehyde $(37.5 \mu \mathrm{L}$, $0.45 \mathrm{mmol})$ is charged to the DME solution followed by the addition of potassium 2-(5methoxybenzofuranyl)trifluoroborate $(42.4 \mathrm{mg}, 0.15 \mathrm{mmol})$. The reaction is stirred at $20{ }^{\circ} \mathrm{C}$ for 24 hours and quenched with $1 \mathrm{M} \mathrm{HCl}(1.0 \mathrm{~mL})$ and is stirred with chloroform $(1.5 \mathrm{~mL})$ for 30 minutes. The organic layer is extracted with chloroform $(2 \times 2.0 \mathrm{~mL})$, 
dried over $\mathrm{Na}_{2} \mathrm{SO}_{4}$, filtered through celite (ether wash) and concentrated in vacuo. Purification by chromatography (silica gel, $15 \%$ ether in pentanes) yields the title compound as clear oil (30.7 mg, 94\% yield, 92\% ee). IR (film) 1724, 1475, 1205, 1030 $\mathrm{cm}^{-1} ;{ }^{1} \mathrm{H}$ NMR $\left(300 \mathrm{MHz}, \mathrm{CD}_{2} \mathrm{Cl}_{2}\right) \delta 9.78(\mathrm{t}, 1 \mathrm{H}, \mathrm{J}=1.5 \mathrm{~Hz}, \mathrm{CHO}), 7.29(\mathrm{~d}, 1 \mathrm{H}, \mathrm{J}=8.4$ $\mathrm{Hz}$, aryl H), $6.98(\mathrm{~d}, 1 \mathrm{H}, \mathrm{J}=2.4 \mathrm{~Hz}$, aryl $\mathbf{H}), 6.81(\mathrm{dd}, 1 \mathrm{H}, \mathrm{J}=2.4,9.0 \mathrm{~Hz}$, aryl $\mathbf{H}), 6.38$ $(\mathrm{d}, 1 \mathrm{H}, \mathrm{J}=0.9 \mathrm{~Hz}), 3.01\left(\mathrm{~s}, 3 \mathrm{H}, \mathrm{OCH}_{3}\right), 3.54\left(\mathrm{~m}, 1 \mathrm{H}, \mathrm{CHCH}_{3}\right), 2.79$ (ddd, $2 \mathrm{H}, \mathrm{J}=1.5$, 6.6, 17.4 Hz, $\mathrm{CH}_{2}$ ), 1.39 (d, 3H, J = 0.9 Hz, CH $\left.\mathbf{C H}_{3}\right) ;{ }^{13} \mathrm{C} \mathrm{NMR}\left(75 \mathrm{MHz}, \mathrm{CDCl}_{3}\right) \delta 201.32$, $163.07,156.46,150.05,129.72,112.37,111.60,103.72,101.93,56.29,49.30,28.78$, 19.18; HRMS (EI+) exact mass calculated for $[\mathrm{M}]^{+\bullet}\left(\mathrm{C}_{13} \mathrm{H}_{14} \mathrm{O}_{3}\right)$ requires $\mathrm{m} / z$ 218.0943, found $m / z$ 218.0944; $[\alpha]_{\mathrm{D}}=-8.51\left(\mathrm{c}=1.29, \mathrm{CHCl}_{3}\right)$. The enantiomeric excess was determined by SFC using a Chiracel OJ-H column (5\% to $10 \% \mathrm{MeCN}$, linear gradient, 100 bar, $35^{\circ} \mathrm{C}$ oven, flow $\left.=4.0 \mathrm{~mL} / \mathrm{min}\right) ;(S)$ isomer $\mathrm{t}_{\mathrm{r}}=5.17 \mathrm{~min},(R)$ isomer $\mathrm{t}_{\mathrm{r}}=5.61$ $\min$.

Determination of the absolute stereochemistry of (R)-3-(5methoxybenzofuran-2-yl)butanal by correlation to $(R)-3-(5-m e t h o x y b e n z o f u r a n-2-$ yl)butan-1-ol. ${ }^{8}$ To a stirring solution of the aldehyde $(25 \mathrm{mg}, 0.11 \mathrm{mmol})$ in $\mathrm{CH}_{2} \mathrm{Cl}_{2}(2.0$ $\mathrm{mL})$ and ethanol $(20 \mu \mathrm{L})$ at $0{ }^{\circ} \mathrm{C}$ was added $\mathrm{NaBH}_{4}(13 \mathrm{mg}, 0.34 \mathrm{mmol})$. The reaction was quenched after 5 minutes by a saturated solution of Rochelle's salt $(2.0 \mathrm{~mL})$. The organic was extracted with ether $(2 \times 3.0 \mathrm{~mL})$ and concentrated in vacuo to yield a clear oil (quantitative yield) with spectroscopic data matching literature values. IR (film) 3306 (br), 2922, 1458, 1201, $1026 \mathrm{~cm}^{-1}$; ${ }^{1} \mathrm{H}$ NMR (300 MHz, $\left.\mathrm{CDCl}_{3}\right) \delta 7.28$ (d, 1H, J = 8.7 Hz, $\operatorname{aryl} \mathbf{H}), 6.94(\mathrm{~d}, 1 \mathrm{H}, \mathrm{J}=2.7 \mathrm{~Hz}$, aryl $\mathbf{H}), 6.79(\mathrm{dd}, 1 \mathrm{H}, \mathrm{J}=2.7,8.7 \mathrm{~Hz}$, aryl H), 6.33 (s, $1 \mathrm{H}$, aryl H), $3.81\left(\mathrm{~s}, 3 \mathrm{H}, \mathrm{OCH}_{3}\right), 3.69\left(\mathrm{~m}, 2 \mathrm{H}, \mathrm{CH}_{2} \mathrm{CH}_{2}\right), 3.11\left(\mathrm{~m}, 1 \mathrm{H}, \mathrm{CHCH}_{3}\right), 2.06-$ $1.95\left(\mathrm{~m}, 1 \mathrm{H}, \mathrm{CH}_{2} \mathrm{OH}\right), 1.91-1.79\left(\mathrm{~m}, 1 \mathrm{H}, \mathrm{CH}_{2} \mathrm{OH}\right), 1.57$ (br s, 1H, OH), 1.34 (d, 3H, J = $\left.7.2 \mathrm{~Hz}, \mathrm{CH}_{3}\right) ;{ }^{13} \mathrm{C}$ NMR $\left(75 \mathrm{MHz}, \mathrm{CDCl}_{3}\right) \delta 164.11,155.98,149.73,129.48,111.81$, 111.38, 103.45, 101.40, 60.97, 56.16, 38.53, 30.56, 19.38; HRMS (EI+) exact mass

(8) Hughes, C. C.; Trauner, D. Tetrahedron, 2004, 60, 9675 (reported $[\alpha]_{D}=-33.0\left(\mathrm{c}=1.00, \mathrm{CHCl}_{3}\right)$ for a product that was $91 \%$ ee). 
calculated for $[\mathrm{M}+1]\left(\mathrm{C}_{13} \mathrm{H}_{16} \mathrm{O}_{3}\right)$ requires $m / z$ 220.1100, found $\mathrm{m} / \mathrm{z} 220.1089 ;[\alpha]_{D}=-46.2$ $\left(\mathrm{c}=0.83, \mathrm{CHCl}_{3}\right){ }^{6}{ }^{6}$ The enantiomeric excess was determined by SFC analysis using a Chiralcel OJ-H column (5\% to $10 \%$ methanol, linear gradient, 100 bar, $35{ }^{\circ} \mathrm{C}$ oven, flow $=4.0 \mathrm{~mL} / \mathrm{min}) ;(S)$ isomer $\mathrm{t}_{\mathrm{r}}=5.71 \mathrm{~min},(R)$ isomer $\mathrm{t}_{\mathrm{r}}=6.56 \mathrm{~min}$.

Determination of the absolute stereochemistry of $(R)-3-(5-$ methoxybenzofuran-2-yl)butanal by obtaining a crystal structure of $(R)-3-(5-$ methoxybenzofuran-2-yl)butyl 4-bromobenzoate (vide $S$ 17). Esterification of (R)-3(5-methoxybenzofuran-2-yl)butan-1-ol (22 $\mathrm{mg}, 0.10 \mathrm{mmol})$ proceeded in a solution of $\mathrm{CH}_{2} \mathrm{Cl}_{2}(1.0 \mathrm{~mL})$ to which $\mathrm{NEt}_{3}(21 \mu \mathrm{L}, 0.15 \mathrm{mmol})$ and DMAP $(1.2 \mathrm{mg}, 0.01 \mathrm{mmol})$ were added. The solution was then cooled to $0{ }^{\circ} \mathrm{C}$ and $p$ - $\mathrm{Br}$ benzoyl chloride $(24 \mathrm{mg}$, 0.11 mmol) was added. The ice bath was removed and after 30 minutes at room temperature, $0.5 \mathrm{M} \mathrm{HCl}(2.0 \mathrm{~mL})$ was added to quench the reaction. The organic layer was dried with $\mathrm{Na}_{2} \mathrm{SO}_{4}$, triturated diethyl ether, filtered (to remove salt impurities) and concentrated in vacuo to yield a yellow solid (34 mg, 85\% yield). IR (film) 2929, 1719, 1591, 1477, 1271, 1205, 1102, 1012, $756.3 \mathrm{~cm}^{-1} ;{ }^{1} \mathrm{H}$ NMR (400 MHz, $\left.\mathrm{CDCl}_{3}\right) \delta 7.74$ (d, $2 \mathrm{H}, \mathrm{J}=8.4 \mathrm{~Hz}$, aryl $\mathbf{H}), 7.47(\mathrm{~d}, 2 \mathrm{H}, \mathrm{J}=8.4 \mathrm{~Hz}$, aryl $\mathbf{H}), 7.22(\mathrm{~s}, 1 \mathrm{H}, \operatorname{aryl} \mathbf{H}), 6.89(\mathrm{~d}$, $1 \mathrm{H}, \mathrm{J}=2.8 \mathrm{~Hz}, \operatorname{aryl} \mathbf{H}), 6.77(\mathrm{dd}, 1 \mathrm{H}, \mathrm{J}=2.8,9.2 \mathrm{~Hz}$, aryl $\mathbf{H}), 6.32(\mathrm{~s}, 1 \mathrm{H}, \operatorname{aryl} \mathbf{H}), 4.33$ (m, 2H, $\left.\mathbf{C H}_{2} \mathrm{OC}(\mathrm{O})\right), 3.78\left(\mathrm{~s}, 3 \mathrm{H}, \mathrm{OCH}_{3}\right), 3.11\left(\mathrm{~m}, 1 \mathrm{H}, \mathrm{CH}_{3} \mathrm{CH}\right), 2.25-2.01\left(\mathrm{~m}, 2 \mathrm{H}, \mathrm{CH}_{2}\right)$, 1.37 (t, 3H, J = 7.2 Hz, CHCH $\left.{ }_{3}\right) ;{ }^{13} \mathrm{C}$ NMR $\left(100 \mathrm{MHz}, \mathrm{CDCl}_{3}\right) \delta 165.95,163.18,155.97$, 149.75, 131.76, 131.17, 129.40, 129.18, 128.11, 111.85, 111.32, 103.42, 101.62, 63.41, 56.10, 34.32m 31.20, 19.23; HRMS (EI+) exact mass calculated for $\left[\mathrm{M}^{+*}\right]\left(\mathrm{C}_{20} \mathrm{H}_{19} \mathrm{O}_{4} \mathrm{Br}\right)$ requires $m / z$ 402.0467, found $m / z$ 402.0481; $[\alpha]_{\mathrm{D}}=-52.7\left(\mathrm{c}=1.02, \mathrm{CHCl}_{3}\right)$.

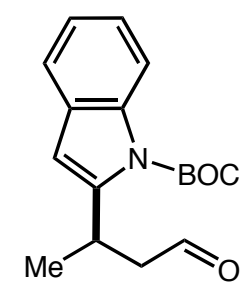


tert-butyl 2-((R)-1-formylpropan-2-yl)-1H-indole-1-carboxylate (Table 2, entry 7). Prepared according to the general procedure using crotonaldehyde and potassium 2-(tert-butyl $1 H$-indole-1-carboxylate)trifluoroborate. To a plastic vial is added HF (48 wt $\%, 3.5 \mathrm{mg}, 0.083 \mathrm{mmol})$ followed by DME $(250 \mu \mathrm{L})$ and a magnetic stir bar. The catalyst and acid co-catalyst are charged to the vial with the addition of $(2 S, 5 S)$ 2-tert-butyl-5-((1-benzyl-1H-indol-3-yl)methyl)-3-methylimidazolidin-4-one (12.4 mg, $0.033 \mathrm{mmol}$ ) and $\mathrm{HCl}\left(4 \mathrm{~N}\right.$ in dioxane, $8.3 \mu \mathrm{L}, 0.033 \mathrm{mmol}$ ) and is then cooled to $-20{ }^{\circ} \mathrm{C}$. Crotonaldehyde (21.0 $\mu \mathrm{L}, 0.25 \mathrm{mmol}$ ) is charged to the DME solution followed by the addition of potassium 2-(tert-butyl $1 H$-indole-1-carboxylate)trifluoroborate (26.9 mg, $0.083 \mathrm{mmol}$ ). The reaction is stirred at $-20{ }^{\circ} \mathrm{C}$ for 24 hours and quenched with $1 \mathrm{M} \mathrm{HCl}$ $(1.0 \mathrm{~mL})$ and is stirred with chloroform $(1.5 \mathrm{~mL})$ for 30 minutes. The organic layer is extracted with chloroform $(2 \times 2.0 \mathrm{~mL})$, dried over $\mathrm{Na}_{2} \mathrm{SO}_{4}$, filtered through celite (ether wash) and concentrated in vacuo. Purification by chromatography (silica gel, $10 \%$ ether in pentanes) yields the title compound as light yellow oil (19.0 mg, 79\% yield, 91\% ee). IR (film) 1728, 1455, 1370, 1327, 1157, $747.4 \mathrm{~cm}^{-1} ;{ }^{1} \mathrm{H}$ NMR (300 MHz, $\left.\mathrm{CDCl}_{3}\right) \delta 9.77$ $(\mathrm{t}, 1 \mathrm{H}, \mathrm{J}=1.8 \mathrm{~Hz}, \mathrm{CHO}), 8.03(\mathrm{dt}, 1 \mathrm{H}, \mathrm{J}=0.6,7.8 \mathrm{~Hz}$, aryl $\mathbf{H}), 7.45(\mathrm{~m}, 1 \mathrm{H}$, aryl $\mathbf{H})$, 7.26-7.15 (m, 2H, aryl H), $6.40(\mathrm{t}, 1 \mathrm{H}, \mathrm{J}=0.9$, aryl $\mathbf{H}), 4.24\left(\mathrm{~m}, 1 \mathrm{H}, \mathbf{C H C H}_{3}\right), 2.57$ (dd, $\left.1 \mathrm{H}, \mathbf{C H}_{2}\right), 2.89\left(1 \mathrm{H}, \mathrm{dd}, \mathrm{J}=1.8,5.4 \mathrm{~Hz}, \mathrm{CH}_{2}\right), 1.37\left(\mathrm{t}, 3 \mathrm{H}, \mathrm{J}=6.9 \mathrm{~Hz}, \mathrm{CH}_{3}\right) ;{ }^{13} \mathrm{C} \mathrm{NMR}$ $\left(75 \mathrm{MHz}, \mathrm{CDCl}_{3}\right) \delta 201.95,150.69,145.80,129.22,123.96,123.00,120.28,115.94$, 106.42, 84.47, 50.80, 28.45, 28.02, 21.06; HRMS (EI+) exact mass calculated for [ $\left.\mathrm{M}^{+*}\right]$ $\left(\mathrm{C}_{17} \mathrm{H}_{21} \mathrm{NO}_{3}\right)$ requires $\mathrm{m} / \mathrm{z}$ 287.1521, found $\mathrm{m} / \mathrm{z} 287.1533$; $[\alpha]_{D}=-6.1\left(\mathrm{c}=0.6, \mathrm{CHCl}_{3}\right)$. The enantiomeric excess was determined by SFC analysis using a Chiralcel OD-H column (5\% to $50 \% \mathrm{MeCN}$, linear gradient, $100 \mathrm{bar}, 35^{\circ} \mathrm{C}$ oven, flow $\left.=4.0 \mathrm{~mL} / \mathrm{min}\right) ;(S)$ isomer $\mathrm{t}_{\mathrm{r}}=2.51 \mathrm{~min},(R)$ isomer $\mathrm{t}_{\mathrm{r}}=2.97 \mathrm{~min}$. 


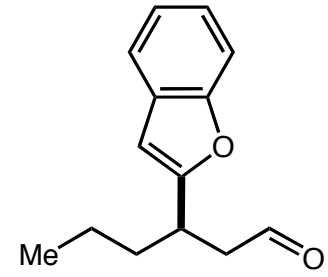

(R)-3-(benzofuran-2-yl) hexanal (Table 3, entry 2). Prepared according to the general procedure using hexenal and potassium 2-benzofuranyltrifluoroborate. To a plastic vial is added HF (48 wt\%, $7.00 \mathrm{mg}, 0.167 \mathrm{mmol}$ ) followed by DME (500 $\mu \mathrm{L})$ and a magnetic stir bar. The catalyst and acid co-catalyst are charged to the vial with the addition of $\quad(2 S, \quad 5 S)$-2-tert-butyl-5-((1-benzyl-1H-indol-3-yl)methyl)-3methylimidazolidin-4-one $(12.5 \mathrm{mg}, 0.033 \mathrm{mmol})$ and $\mathrm{HCl}(4 \mathrm{~N}$ in dioxane, $8.30 \mu \mathrm{L}$, $0.033 \mathrm{mmol})$ and is then cooled to $4{ }^{\circ} \mathrm{C}$. Hexenal $(58.0 \mu \mathrm{L}, 0.50 \mathrm{mmol})$ is charged to the DME solution followed by the addition of potassium 2-benzofuranyltrifluoroborate (37.3 $\mathrm{mg}, 0.167 \mathrm{mmol})$. The reaction is stirred at $4{ }^{\circ} \mathrm{C}$ for 12 hours and quenched with a saturated solution of Rochelle's salt $(1.0 \mathrm{~mL})$ and is partitioned with dichloromethane (2 x $1.5 \mathrm{~mL}$ ). The combined organic layers are dried over $\mathrm{Na}_{2} \mathrm{SO}_{4}$, concentrated in vacuo and purified by chromatography (silica gel, $10 \%$ ether in pentanes) to yield the title compound as clear oil (34.9 mg, 97\% yield, 93\% ee). IR (film) 2959, 2932, 2873, 1725, 1456, 1253, $751.8 \mathrm{~cm}^{-1} ;{ }^{1} \mathrm{H}$ NMR (300 $\mathrm{MHz} \mathrm{CDCl}_{3}$ ) $\delta 9.75$ (s, 1H, CHO), 7.49-7.38 (m, 2H, aryl H), 7.24-7.14 (m, 2H, aryl H), 6.42 (s, 1H, 3'-benzofuran $\mathbf{H}), 3.48-3.39$ (m, 1H, $\left.\mathrm{CH}_{2} \mathrm{CHCH}_{2}\right), 2.80\left(\mathrm{ddd}, 2 \mathrm{H}, \mathrm{J}=1.8,7.5,17.1 \mathrm{~Hz}, \alpha-\mathrm{CH}_{2}\right), 1.85-1.58\left(\mathrm{~m}, 2 \mathrm{H}, \mathrm{CH}_{2}\right), 1.37-$ $1.24\left(\mathrm{~m}, 2 \mathrm{H}, \mathrm{CH}_{2}\right), 0.89$ (t, 3H, J = 6.9 Hz, CH$\left.) ;{ }^{13} \mathrm{C} \mathrm{NMR} \mathrm{(125} \mathrm{MHz,} \mathrm{CDCl}_{3}\right) \delta 201.31$, $147.98,132.55,123.73,122.82,120.73,111.12,102.85,67.13,47.70,35.97,33.69$, 20.48, 14.07; HRMS (EI+) exact mass calculated for $[\mathrm{M}]^{+\bullet}\left(\mathrm{C}_{14} \mathrm{H}_{16} \mathrm{O}_{2}\right)$ requires $\mathrm{m} / \mathrm{z}$ 216.1150, found $m / z, 216.1142 ;[\alpha]_{D}=-7.3\left(c=1.05, \mathrm{CHCl}_{3}\right)$. The enantiomeric excess was determined on the alcohol product, which was prepared by a $\mathrm{NaBH}_{4}$ reduction, and analyzed by SFC using a Chiralpak AS-H column (5\% to 25\% IPA, linear gradient, 100 bar, $35^{\circ} \mathrm{C}$ oven, flow $\left.=4.0 \mathrm{~mL} / \mathrm{min}\right) ;(S)$ isomer $\mathrm{t}_{\mathrm{r}}=3.18 \mathrm{~min},(R)$ isomer $\mathrm{t}_{\mathrm{r}}=3.36 \mathrm{~min}$. 


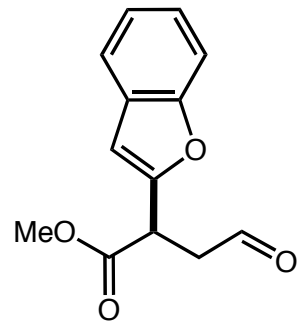

(R)-methyl 2-(benzofuran-2-yl)-3-formylpropanoate (Table 3, entry 3). Prepared according to the general procedure using $(E)$-methyl 3-formylacrylate and potassium 2-benzofuranyltrifluoroborate. To a plastic vial is added HF (48 wt\%, 7.00 $\mathrm{mg}, 0.167 \mathrm{mmol})$ followed by DME $(500 \mu \mathrm{L})$ and a magnetic stir bar. The catalyst and acid co-catalyst are charged to the vial with the addition of $(2 S, 5 S)$-2-tert-butyl-5-((1benzyl-1H-indol-3-yl)methyl)-3-methylimidazolidin-4-one $(12.5 \mathrm{mg}, 0.033 \mathrm{mmol})$ and $\mathrm{HCl}(4 \mathrm{~N}$ in dioxane, $8.30 \mu \mathrm{L}, 0.033 \mathrm{mmol})$ and is then cooled to $-20{ }^{\circ} \mathrm{C}$. (E)-Methyl 3formylacrylate $(58.0 \mu \mathrm{L}, 0.50 \mathrm{mmol})$ is charged to the DME solution followed by the addition of potassium 2-benzofuranyltrifluoroborate $(37.3 \mathrm{mg}, 0.167 \mathrm{mmol})$. The reaction is stirred at $-20{ }^{\circ} \mathrm{C}$ for 18 hours and quenched with $1 \mathrm{M} \mathrm{HCl}(1.0 \mathrm{~mL})$ and is stirred in chloroform $(1.5 \mathrm{~mL})$ for 30 minutes. The organic layer is extracted with chloroform ( 2 x $2.0 \mathrm{~mL}$ ), dried over $\mathrm{Na}_{2} \mathrm{SO}_{4}$, concentrated in vacuo and purified by chromatography (silica gel, $25 \%$ ether in pentanes) to yield the title compound as clear oil (36.0 mg, 93\% yield, $88 \%$ ee). IR (film) 1736, 1720, 1453, 1168, $750.9 \mathrm{~cm}^{-1} ;{ }^{1} \mathrm{H}$ NMR (300 MHz, $\left.\mathrm{CDCl}_{3}\right) \delta 9.82(\mathrm{~s}, 1 \mathrm{H}, \mathrm{CHO})$, 7.52-7.40 (m, 2H, aryl H), 7.28-7.17 (m, 2H, aryl H), 6.58 (s, 1H, 3'-benzofuran $\mathbf{H}), 4.42\left(\mathrm{dd}, 1 \mathrm{H}, \mathrm{J}=5.1,9.0 \mathrm{~Hz}, \mathrm{CHCH}_{2}\right), 3.73$ (s, 3H, $\mathrm{OCH}_{3}$ ), 3.45 (ddd, 1H, J = 0.6, 9.0, $18.6 \mathrm{~Hz}, \mathrm{CH}_{2}$ ), 3.02 (ddd, 1H, J = 0.6, 5.1, $\left.18.6 \mathrm{~Hz}, \mathrm{CH}_{2}\right) ;{ }^{13} \mathrm{C}$ NMR $\left(75 \mathrm{MHz}, \mathrm{CDCl}_{3}\right) \delta 198.82,191.57,147.97,132.45,128.33$, 124.52, 123.18, 121.14, 111.42, 104.62, 53.120, 44.37, 39.39; HRMS (EI+) exact mass calculated for $[\mathrm{M}]^{+\bullet}\left(\mathrm{C}_{13} \mathrm{H}_{12} \mathrm{O}_{4}\right)$ requires $m / z$ 232.0736, found $m / z$ 232.0728; $[\alpha]_{D}=-95.0$ $\left(\mathrm{c}=0.8, \mathrm{CHCl}_{3}\right)$. The enantiomeric excess was determined on the diol product, which is prepared by reduction of the ester and aldehyde $(21.5 \mathrm{mg}, 0.093 \mathrm{mmol})$ in THF $(1 \mathrm{~mL})$ using $\mathrm{LiAlH}_{4}(1 \mathrm{M}$ in THF, $200 \mu \mathrm{L}, 0.2 \mathrm{mmol})$ at $-60^{\circ} \mathrm{C}$. SFC analysis was performed 
using a Chiralpak AD-H column (5\% to $15 \%$ methanol, linear gradient, 100 bar, $35{ }^{\circ} \mathrm{C}$ oven, flow $=4.0 \mathrm{~mL} / \mathrm{min}) ;(S)$ isomer $\mathrm{t}_{\mathrm{r}}=10.23 \mathrm{~min},(R)$ isomer $\mathrm{t}_{\mathrm{r}}=10.80 \mathrm{~min}$.

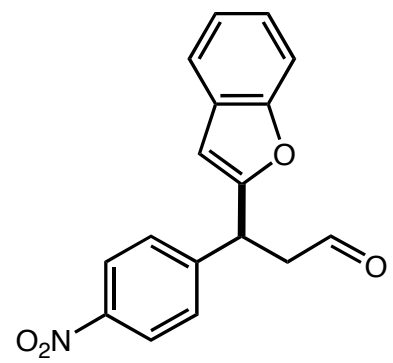

(S)-3-(Benzofuran-2-yl)-3-(4-nitrophenyl)propanal (Table 3, entry 5).

Prepared according to the general procedure using $p$-nitrocinnamaldehyde and potassium 2-benzofuranyltrifluoroborate. To a plastic vial is added HF (48 wt\%, $3.50 \mathrm{mg}, 0.083$ mmol) followed by DME $(250 \mu \mathrm{L})$ and a magnetic stir bar. The catalyst and acid cocatalyst are charged to the vial with the addition of (2S, $5 S)$-2-tert-butyl-5-((1-benzyl-1Hindol-3-yl)methyl)-3-methylimidazolidin-4-one $(6.26 \mathrm{mg}, 0.017 \mathrm{mmol})$ and $\mathrm{HCl}(4 \mathrm{~N}$ in dioxane, $4.20 \mu \mathrm{L}, 0.017 \mathrm{mmol})$. $p$-Nitrocinnamaldehye $(44.3 \mathrm{mg}, 0.250 \mathrm{mmol})$ is charged to the DME solution followed by the addition of potassium 2benzofuranyltrifluoroborate $(18.7 \mathrm{mg}, 0.083 \mathrm{mmol})$. The reaction is stirred at ambient temperature for 24 hours and quenched with a saturated solution of Rochelle's salt (1.0 $\mathrm{mL})$ and is then partitioned with dichloromethane $(2 \times 1.5 \mathrm{~mL})$. The combined organic layers are dried over $\mathrm{Na}_{2} \mathrm{SO}_{4}$, concentrated in vacuo and purified by chromatography (prep TLC, 25\% dichloromethane in benzene) to yield the title compound as a light yellow oil (16.9 mg, 69\% yield, 92\% ee). IR (film) 1724, 1519, 1454, 1347, 1254, 752.1 $\mathrm{cm}^{-1} ;{ }^{1} \mathrm{H}$ NMR (300 MHz, $\left.\mathrm{CDCl}_{3}\right) \delta 9.81(\mathrm{~s}, 1 \mathrm{H}, \mathrm{CHO}), 8.19(\mathrm{~d}, 2 \mathrm{H}, \mathrm{J}=8.4 \mathrm{~Hz}$, aryl H), 7.53-7.39 (m, 4H, aryl H), 7.28-7.18 (m, 2H, aryl H), 6.50 (s, 1H, 3'-benzofuran H), 4.90 $\left(\mathrm{t}, 1 \mathrm{H}, \mathrm{J}=7.2 \mathrm{~Hz}, \mathrm{CH}_{2} \mathrm{CH}\right), 3.32\left(\mathrm{dd}, 2 \mathrm{H}, \mathrm{J}=6.9,17.7 \mathrm{~Hz}, \mathrm{CH}_{2}\right) ;{ }^{13} \mathrm{C}$ NMR $(125 \mathrm{MHz}$, $\left.\mathrm{CDCl}_{3}\right) \delta 198.65,157.20,147.99,129.13,124.55,124.30,123.25,121.11,111.32$, 104.11, 47.82, 39.16; HRMS (EI+) exact mass calculated for $[\mathrm{M}]^{+\bullet}\left(\mathrm{C}_{17} \mathrm{H}_{13} \mathrm{NO}_{4}\right)$ requires $m / z$ 295.0845, found $m / z$ 295.0853; $[\alpha]_{D}=48.7\left(\mathrm{c}=1.0, \mathrm{CHCl}_{3}\right)$. The enantiomeric 
excess was determined on the alcohol product, which was prepared by a $\mathrm{NaBH}_{4}$ reduction, and analyzed by SFC using a Chiralpak AS-H column (5\% to $25 \%$ methanol, linear gradient, $100 \mathrm{bar}, 35^{\circ} \mathrm{C}$ oven, flow $\left.=4.0 \mathrm{~mL} / \mathrm{min}\right) ;(S)$ isomer $\mathrm{t}_{\mathrm{r}}=6.93 \mathrm{~min},(R)$ isomer $\mathrm{t}_{\mathrm{r}}=7.22 \mathrm{~min}$.

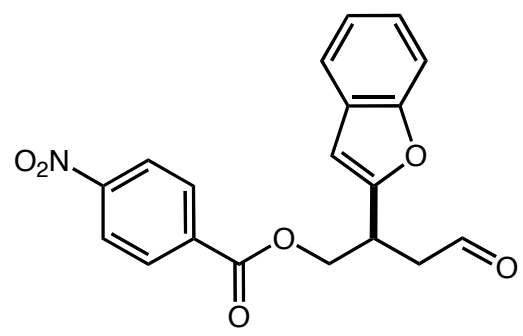

(S)-2-(benzofuran-2-yl)-3-formylpropyl 4-nitrobenzoate (Table 3, entry 4). Prepared according to the general procedure using $(E)$-3-formylallyl 4-nitrobenzoate and potassium 2-benzofuranyltrifluoroborate. To a plastic vial is added HF (48 wt\%, $2.1 \mathrm{mg}$, $0.05 \mathrm{mmol})$ followed by DME $(150 \mu \mathrm{L})$ and a magnetic stir bar. The catalyst and acid co-catalyst are charged to the vial with the addition of (2S,5S)-2-tert-butyl-5-((1-benzyl$1 H$-indol-3-yl)methyl)-3-methylimidazolidin-4-one $(7.51 \mathrm{mg}, 0.02 \mathrm{mmol})$ and $\mathrm{HCl}(4 \mathrm{~N}$ in dioxane, $5.0 \mu \mathrm{L}, 0.02 \mathrm{mmol}$ ). (E)-3-Formylallyl 4-nitrobenzoate (35.3 mg, 0.15 mmol) is charged to the DME solution followed by the addition of potassium 2benzofuranyltrifluoroborate $(11.2 \mathrm{mg}, 0.05 \mathrm{mmol})$. The reaction is stirred at $-20{ }^{\circ} \mathrm{C}$ for 23 hours and quenched with $1 \mathrm{M} \mathrm{HCl}(1.0 \mathrm{~mL})$ and is stirred with chloroform $(1.5 \mathrm{~mL})$ for 30 minutes. The organic layer is extracted with chloroform $(2 \times 2.0 \mathrm{~mL})$, dried over $\mathrm{Na}_{2} \mathrm{SO}_{4}$, concentrated in vacuo and purified by chromatography (prep TLC, $40 \%$ dichloromethane in benzene) to yield the title compound as a yellow oil (13.3 $\mathrm{mg}, 75 \%$ yield, $89 \%$ ee). IR (film) 1725, 1526, 1348, 1272, 1120, 1103, 752.6, $718.2 \mathrm{~cm}^{-1} ;{ }^{1} \mathrm{H}$ NMR (300 MHz, CDCl $\left.)_{3}\right) \oint .84$ (t, 1H, J = 1.2 Hz, CHO), 8.19 (dd, 4H, J = 2.1, 39.9 Hz, aryl H), 7.45 (dd, 2H, J = 7.5, 27.6 Hz, aryl H), 7.28-7.17 (m, 2H, aryl H), 6.57 (s, 1H, 3'-benzofuran H), 4.66 (dd, 2H, J = 6.3, $\left.10.8 \mathrm{~Hz}, \mathrm{CH}_{2} \mathrm{OBz}\right)$, 4.07-3.98 (m, 1H, CHCH $\mathbf{H C}_{2}$, $3.04\left(\mathrm{ddd}, 2 \mathrm{H}, \mathrm{J}=1.2,6.6,18.0 \mathrm{~Hz}, \mathrm{CHCH}_{2}\right) ;{ }^{13} \mathrm{C} \mathrm{NMR}\left(75 \mathrm{MHz}, \mathrm{CDCl}_{3}\right) \delta 199.20$, $164.53,156.03,135.21,130.98,128.29,124.44,123.85121 .08,111.25,104.05,66.47$, 
44.23, 33.31; HRMS (EI+) exact mass calculated for $[\mathrm{M}]^{+\bullet}\left(\mathrm{C}_{19} \mathrm{H}_{15} \mathrm{NO}_{6}\right)$ requires $\mathrm{m} / \mathrm{z}$ 353.0899, found $m / z$ 353.0885; $[\alpha]_{\mathrm{D}}=+6.29\left(\mathrm{c}=1.06, \mathrm{CHCl}_{3}\right)$. The enantiomeric excess was determined on the alcohol product, which was prepared by a $\mathrm{NaBH}_{4}$ reduction, and analyzed by SFC using a Chiralpak AD-H column (30\% to 50\% methanol, linear gradient, 100 bar, $35^{\circ} \mathrm{C}$ oven, flow $\left.=4.0 \mathrm{~mL} / \mathrm{min}\right) ;(S)$ isomer $\mathrm{t}_{\mathrm{r}}=5.78 \mathrm{~min},(R)$ isomer $\mathrm{t}_{\mathrm{r}}$ $=6.34 \mathrm{~min}$. 
Crystal Structure Analysis of:

\section{4-Bromobenzoic Acid (R)-3-(5-Methoxybenzofuran-2-yl)butyl Ester (DWCM003)}

For Investigator: Sandra Lee

Advisor: David W. C. MacMillan

By Douglas M. Ho

\section{Contents}

Experimental

Table 1. Crystal data

Table 2. Data Collection

Table 3. Refinement

Table 4. Atomic Coordinates

Table 5. Anisotropic atomic displacement parameters for dwcm003f

Table 6. Geometric parameters $\left(\AA{ }^{\circ}\right)$ for dwcm003f

Computer programs

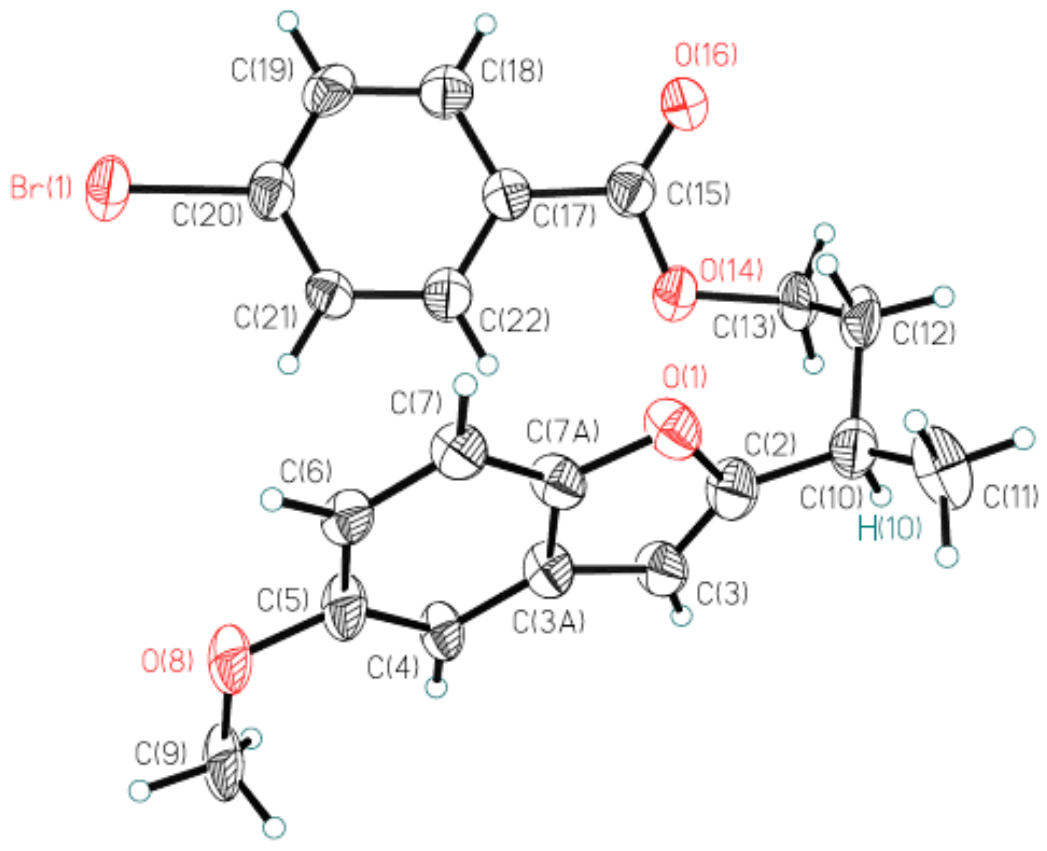

4-Bromobenzoic Acid (R)-3-(5-Methoxybenzofuran-2-yl)butyl Ester (DWCM003) 


\section{Experimental}

Evaporation of a carbon disulfide solution of the compound yielded a yellow oil. Upon standing at room temperature for a number of hours, the oil crystallized into colorless bundles of intergrown plates. A fragment approximately $0.03 \mathrm{~mm}$ x $0.08 \mathrm{~mm} \times$ $0.25 \mathrm{~mm}$ in size was cut from one of the plates, mounted on a glass fiber with silicone grease and transferred to a Nonius KappaCCD diffractometer equipped with an MSC Xstream cryosystem and Mo $\mathrm{K} \alpha$ radiation $(\lambda=0.71073 \AA$ ) $)$. Fourteen hundred and forty frames of data were collected at 200(2) K with an $\omega$ oscillation range of $0.5^{\circ} /$ frame, and an exposure time of $60 \mathrm{~s} / \mathrm{deg} .{ }^{9}$ A total of 7927 reflections $\left(\theta_{\max }=22.46^{\circ}\right)$ were indexed, integrated and corrected for Lorentz and polarization effects using DENZO-SMN and SCALEPACK..$^{10}$ The crystal did not exhibit any usable data beyond that $\theta_{\max }$ value. Therefore, a standard $0.76961 \AA\left(\theta_{\max }=27.5^{\circ}\right)$ data set was not warranted or pursued. Gaussian and $\psi$-scan absorption corrected data sets were also examined but did not lead to improved refinement results and were therefore not pursued further as well. Data reduction yielded 2296 unique reflections $\left(\mathrm{R}_{\mathrm{int}}=0.066\right)$ of which 1735 had $I>2 \sigma(I)$. Postrefinement of the unit cell parameters gave $a=5.8677(3) \AA, b=7.3771(5) \AA, c=$ 20.8583(14) $\AA, \alpha=90^{\circ}, \beta=97.998(4)^{\circ}, \gamma=90^{\circ}$, and $V=894.1(1) \AA^{3}$. Axial photographs and systematic absences were consistent with the compound having crystallized in one of two possible monoclinic space groups, i.e., P $2_{1}$ or $\mathrm{P} 2_{1} / \mathrm{m}$. The observed mean I $E^{2}-1 \mid$ value was 0.948 (versus the expectation values of 0.968 and 0.736 for centric and noncentric data, respectively). Nevertheless, the chiral space group P $2_{1}$ (No. 4) was selected since the compound was indicated to be optically pure.

The structure was solved by direct methods and refined by full-matrix leastsquares on $F^{2}$ using SHELXTL. ${ }^{11}$ The asymmetric unit was found to contain only a single molecule of 4-bromobenzoic acid (R)-3-(5-methoxybenzofuran-2-yl)butyl ester. All of the nonhydrogen atoms were refined with anisotropic displacement coefficients. The

(9) COLLECT.; Nonius BV: Delft, The Netherlands, 1998.

(10) Otwinowski, Z.; Minor, W. In Methods in Enzymology; Carter, C. W., Sweet, R. M., Eds.; MacMomolecular Crystallography, Part A; Academic Press: New York, 1997; pp 307-326.

(11) Sheldrick, G. M. SHELXTL, version 5.04; Siemens Analytical X-ray Instruments, Inc.: Madison, WI, 1996. 
hydrogen atoms were assigned isotropic displacement coefficients $U(\mathrm{H})=1.2 U(\mathrm{C})$ or $1.5 U\left(\mathrm{C}_{\text {methy }}\right)$, and their coordinates were allowed to ride on their respective carbons. The sample was also found to be twinned with the volume fractions of the twin components being 0.9774(6) and 0.0226(6). Convergence of this single molecule model gave $w R\left(F^{2}\right)$ $=0.1141$ for 2296 unique reflections of which 1735 had $I>2 \sigma(I), 227$ parameters and 199 restraints. This model, however, gave atoms exhibiting large thermal vibrations, and was therefore abandoned in favor of a two-site whole molecule disorder model. Initial occupancy refinement tests yielded site occupancy factors of 0.45(4) and 0.55(4) for the atoms of the two sites indicating that each site was half-occupied within the errors of the experiment. A whole molecule disorder model consisting of two exactly half-occupied molecules was therefore selected. Distance, similarity and common plane restraints were employed due to the close proximity of the two half molecules. The weighting scheme employed was $w=1 /\left[\sigma^{2}\left(F_{o}^{2}\right)+0.1541 P\right]$ where $P=\left(F_{o}^{2}+2 F_{c}^{2}\right) / 3$. The refinement converged to $R(F)=0.0483, w R\left(F^{2}\right)=0.0910$, and $S=1.224$ for 1735 reflections with $I>$ $2 \sigma(I)$, and $R(F)=0.0741, w R\left(F^{2}\right)=0.1017$, and $S=1.142$ for 2296 unique reflections, 451 parameters and 724 restraints. The maximum $|\Delta / \sigma|$ in the final cycle of least-squares was 0.001 , and the residual peaks on the final difference-Fourier map ranged from -0.256 to $0.354 \mathrm{e}^{-3}$. The $R$-factor ratio between the $w R\left(F^{2}\right)$ values for the single molecule model and the whole molecule disorder model is $R=0.1141 / 0.1017=1.12$ while $R_{224,2069,0.005}=1.07$, i.e., $R>R_{224,2069,0.005 .}{ }^{12}$ Hence, the notion that the model without whole molecule disorder might be preferable is convincingly rejected at the 0.005 level. Scattering factors were taken from the International Tables for Crystallography, Volume C. ${ }^{13}$

The Flack parameter refined to 0.04(2) [vs the expectation values of 0 for the correct hand and 1 for the wrong hand] indicating that the coordinates below are for the correct hand of the molecule and that the absolute configuration at the chiral carbon is unequivocally $R$ (IUPAC Numbering: Wanted $=(3 R)$, Found $=(3 R)$; Crystallographic

(12) Hamilton, W. C. Acta Crystallogr. 1965, 18, 502.

(13) Maslen, E. N.; Fox, A. G.; O'Keefe, M. A. International Tables for Crystallography: Mathematical, Physical and Chemical Tables; Wilson, A. J. C., Ed.; Kluwer: Dordrecht, The Netherlands, 1992; Vol. C, pp 476-516. 
Atom Numbering: Wanted $=\left(10 R / 10^{\prime} R\right)$, Found $\left.=\left(10 R / 10^{\prime} R\right)\right){ }^{14}$ Due to the complexity of the molecule, the IUPAC butyl C-3 atom is given the crystallographic label $\mathrm{C} 10$ in the atoms list below. (The $\mathrm{C} 10$ ' atom listed below corresponds to the chiral atom in the second molecule of the two-site whole molecule disorder model employed.)

For comparison, a refinement of the inverted molecule having the wrong absolute structure, i.e., (3S), gave $R(F)=0.0696, w R\left(F^{2}\right)=0.1670$, and $S=1.129$ for 1735 reflections with $I>2 \sigma(I)$, and $R(F)=0.0949, w R\left(F^{2}\right)=0.1858$, and $S=1.052$ for 2296 unique reflections, 451 parameters, and 724 restraints for the whole molecule disorder model. The Flack parameter based on the wrong absolute structure was 0.95(3). Based on these $w R\left(F^{2}\right)$ and Flack values, the $(3 S)$ isomer is soundly rejected.

Table 1. Crystal data

$\mathrm{C}_{20} \mathrm{H}_{19} \mathrm{BrO}_{4}$

$M_{r}=403.26$

Monoclinic, $P 2_{1}$ (No. 4)

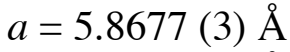

$b=7.3771(5) \AA$

$c=20.8583(14) \AA$

$\beta=97.998(4)^{\circ}$

$V=894.1(1) \AA^{3}$
$Z=2$

$D_{x}=1.498 \mathrm{Mg} \mathrm{m}^{-3}$

Mo $K \alpha$ radiation

Cell parameters from 7927 reflections

$\theta=1.97-22.46^{\circ}$

$\mu=2.32 \mathrm{~mm}^{-1}$

$T=200(2) \mathrm{K}$

Plate, Colorless

Table 2. Data collection

Nonius KappaCCD diffractomer

1735 reflections with $I>2 \sigma(I)$ $\omega$ scans; $14400.5^{\circ}$ rotations

$R_{\text {int }}=0.066$

Absorption correction: none

$\theta_{\text {max }}=22.46^{\circ}$

$h=-6 \rightarrow 6$

7927 measured reflections

$k=-7 \rightarrow 7$

2296 independent reflections

$l=-22 \rightarrow 22$

(14) Flack, H. D. Acta Crystallogr. Sect. A 1983, 39, 876. 
Table 3. Refinement

Refinement on $F^{2}$

$R\left[F^{2}>2 \sigma\left(F^{2}\right)\right]=0.0483$ (obs data)

$w R\left(F^{2}\right)=0.0910$ (obs data)

$S=1.224$ (obs data)

$R\left[F^{2}>2 \sigma\left(F^{2}\right)\right]=0.0741$ (uniq data) $w R\left(F^{2}\right)=0.1017$ (uniq data)

$S=1.142$ (uniq data)

Flack parameter: 0.038 (15)

Absolute structure: ${ }^{14}$
$\mathrm{H}$ atoms constrained to parent site 2296 unique reflections

451 parameters

724 restraints

$|\Delta / \sigma|_{\max }=0.001$

$\Delta \rho_{\max }=0.354$ e $\AA^{-1}$

$\Delta \rho_{\min }=-0.256 \mathrm{e} \AA^{-1}$

Extinction correction: none

Calculated weights $w=1 /\left[\sigma^{2}\left(F_{o}^{2}\right)+\right.$ $0.1541 P]$ where $P=\left(F_{o}^{2}+2 F_{c}^{2}\right) / 3$

Table 4. Atomic site parameters for dwcm003f

$\begin{array}{lllll} & x & y & z & U \\ \text { Br1 } & -0.1992(9) & 0.8493 & 0.0767(3) & 0.0563(13) \\ \text { O1 } & 0.5174(14) & 0.2757(12) & 0.3126(5) & 0.039(2) \\ \text { C2 } & 0.7373(17) & 0.3442(11) & 0.3350(5) & 0.043(3) \\ \text { C3 } & 0.8475(15) & 0.3863(12) & 0.2851(5) & 0.041(3) \\ \text { H3 } & 0.9986 & 0.4350 & 0.2882 & 0.049 \\ \text { C3A } & 0.7002(15) & 0.3461(10) & 0.2259(5) & 0.032(3) \\ \text { C4 } & 0.7143(17) & 0.3591(12) & 0.1597(5) & 0.033(3) \\ \text { H4 } & 0.8492 & 0.4047 & 0.1449 & 0.039 \\ \text { C5 } & 0.5301(18) & 0.3048(12) & 0.1170(5) & 0.039(3) \\ \text { C6 } & 0.3296(17) & 0.2371(13) & 0.1375(5) & 0.033(3) \\ \text { H6 } & 0.2042 & 0.2003 & 0.1064 & 0.039 \\ \text { C7 } & 0.3131(16) & 0.2233(14) & 0.2031(6) & 0.035(3) \\ \text { H7 } & 0.1780 & 0.1776 & 0.2178 & 0.042 \\ \text { C7A } & 0.4998(15) & 0.2785(11) & 0.2463(5) & 0.034(2) \\ \text { O8 } & 0.5136(20) & 0.3079(14) & 0.0504(5) & 0.041(3) \\ \text { C9 } & 0.7208(24) & 0.3394(23) & 0.0232(6) & 0.049(4) \\ \text { H9A } & 0.6869 & 0.3385 & -0.0241 & 0.074 \\ \text { H9B } & 0.8326 & 0.2439 & 0.0375 & 0.074 \\ \text { H9C } & 0.7850 & 0.4575 & 0.0378 & 0.074 \\ \text { C10 } & 0.7945(20) & 0.3537(14) & 0.4060(5) & 0.043(3) \\ \text { H10 } & 0.9547 & 0.4025 & 0.4156 & 0.051 \\ \text { C11 } & 0.7942(32) & 0.1714(18) & 0.4365(6) & 0.050(4) \\ \text { H11A } & 0.8329 & 0.1834 & 0.4836 & 0.075 \\ \text { H11B } & 0.9083 & 0.0940 & 0.4199 & 0.075 \\ \text { H11C } & 0.6412 & 0.1169 & 0.4263 & 0.075\end{array}$




\begin{tabular}{|c|c|c|c|c|}
\hline C12 & $0.6356(26)$ & 0.4817 (19) & $0.4395(6)$ & $0.046(4)$ \\
\hline $\mathrm{H} 12 \mathrm{~A}$ & 0.4738 & 0.4422 & 0.4279 & 0.055 \\
\hline H12B & 0.6757 & 0.4709 & 0.4870 & 0.055 \\
\hline C13 & $0.6563(22)$ & $0.6770(18)$ & $0.4202(6)$ & $0.041(4)$ \\
\hline H13A & 0.5965 & 0.7557 & 0.4526 & 0.049 \\
\hline H13B & 0.8206 & 0.7072 & 0.4200 & 0.049 \\
\hline $\mathrm{O} 14$ & $0.5282(18)$ & $0.7132(15)$ & $0.3560(5)$ & $0.046(3)$ \\
\hline $\mathrm{C} 15$ & 0.3100 (19) & $0.7738(12)$ & $0.3535(5)$ & $0.041(3)$ \\
\hline O16 & $0.2201(23)$ & $0.8108(20)$ & $0.4005(5)$ & $0.054(4)$ \\
\hline $\mathrm{C} 17$ & $0.1954(17)$ & $0.7883(11)$ & $0.2855(5)$ & $0.032(3)$ \\
\hline C18 & $-0.0240(18)$ & 0.8709 (13) & $0.2751(5)$ & $0.040(3)$ \\
\hline H18 & -0.0920 & 0.9144 & 0.3109 & 0.048 \\
\hline C19 & $-0.1399(16)$ & $0.8885(11)$ & $0.2130(5)$ & $0.039(3)$ \\
\hline H19 & -0.2874 & 0.9440 & 0.2059 & 0.047 \\
\hline $\mathrm{C} 20$ & $-0.0392(15)$ & $0.8246(7)$ & $0.1614(4)$ & $0.041(3)$ \\
\hline $\mathrm{C} 21$ & $0.1767(15)$ & $0.7427(11)$ & $0.1705(5)$ & $0.033(3)$ \\
\hline $\mathrm{H} 21$ & 0.2436 & 0.6994 & 0.1345 & 0.040 \\
\hline $\mathrm{C} 22$ & $0.2923(17)$ & $0.7252(13)$ & $0.2325(5)$ & $0.038(3)$ \\
\hline $\mathrm{H} 22$ & 0.4397 & 0.6695 & 0.2391 & 0.045 \\
\hline Br1' & $-0.1809(10)$ & $0.9272(11)$ & $0.0755(3)$ & $0.0726(15)$ \\
\hline $\mathrm{O} 1^{\prime}$ & $0.5261(14)$ & $0.3606(12)$ & $0.3134(5)$ & $0.042(3)$ \\
\hline $\mathrm{C} 2^{\prime}$ & $0.7441(16)$ & 0.4309 (11) & $0.3363(5)$ & $0.041(3)$ \\
\hline C3' & $0.8558(15)$ & $0.4738(13)$ & $0.2866(5)$ & $0.040(4)$ \\
\hline H3' & 1.0062 & 0.5237 & 0.2900 & 0.048 \\
\hline C3A' & $0.7102(14)$ & $0.4318(10)$ & $0.2272(5)$ & $0.039(3)$ \\
\hline $\mathrm{C}^{\prime}$ & $0.7269(15)$ & $0.4447(13)$ & $0.1611(5)$ & $0.033(4)$ \\
\hline H4' & 0.8618 & 0.4914 & 0.1467 & 0.039 \\
\hline $\mathrm{C} 5^{\prime}$ & 0.5443 (17) & $0.3885(12)$ & $0.1181(5)$ & $0.046(3)$ \\
\hline C6 $6^{\prime}$ & $0.3443(17)$ & 0.3195 (14) & $0.1379(5)$ & $0.041(5)$ \\
\hline H6' & 0.2205 & 0.2816 & 0.1066 & 0.049 \\
\hline C7' & $0.3253(17)$ & $0.3058(14)$ & $0.2037(6)$ & $0.040(3)$ \\
\hline H7' & 0.1902 & 0.2590 & 0.2180 & 0.047 \\
\hline $\mathrm{C}^{\prime} \mathrm{A}^{\prime}$ & $0.5104(15)$ & $0.3628(11)$ & $0.2471(5)$ & $0.039(3)$ \\
\hline O8' & 0.5322 (19) & $0.3919(15)$ & $0.0515(5)$ & $0.049(3)$ \\
\hline C9' & $0.7420(24)$ & $0.4290(24)$ & $0.0260(6)$ & $0.046(4)$ \\
\hline H9A' & 0.7126 & 0.4279 & -0.0214 & 0.069 \\
\hline H9B' & 0.8564 & 0.3361 & 0.0410 & 0.069 \\
\hline $\mathrm{H} 9 \mathrm{C}^{\prime}$ & 0.8004 & 0.5484 & 0.0410 & 0.069 \\
\hline C10' & 0.8007 (20) & 0.4419 (14) & $0.4073(5)$ & $0.046(3)$ \\
\hline H10' & 0.9612 & 0.4898 & 0.4170 & 0.055 \\
\hline C11' & $0.7986(37)$ & $0.2589(20)$ & $0.4377(7)$ & $0.074(6)$ \\
\hline H11D & 0.8368 & 0.2703 & 0.4848 & 0.111 \\
\hline $\mathrm{H} 11 \mathrm{E}$ & 0.9125 & 0.1811 & 0.4210 & 0.111 \\
\hline
\end{tabular}




$\begin{array}{lllll}\text { H11F } & 0.6453 & 0.2051 & 0.4272 & 0.111 \\ \text { C12' } & 0.6431(24) & 0.5697(19) & 0.4409(6) & 0.047(4) \\ \text { H12C } & 0.4815 & 0.5293 & 0.4299 & 0.056 \\ \text { H12D } & 0.6849 & 0.5593 & 0.4884 & 0.056 \\ \text { C13' } & 0.6596(23) & 0.7647(20) & 0.4219(6) & 0.050(4) \\ \text { H13C } & 0.5968 & 0.8420 & 0.4540 & 0.060 \\ \text { H13D } & 0.8234 & 0.7973 & 0.4222 & 0.060 \\ \text { O14' } & 0.5337(19) & 0.8008(14) & 0.3575(5) & 0.049(3) \\ \text { C15' } & 0.3155(19) & 0.8615(12) & 0.3539(5) & 0.050(3) \\ \text { O16' } & 0.2219(24) & 0.9006(19) & 0.4000(5) & 0.074(5) \\ \text { C17' } & 0.2047(18) & 0.8735(11) & 0.2853(5) & 0.037(3) \\ \text { C18' } & -0.0179(17) & 0.9502(15) & 0.2740(5) & 0.041(3) \\ \text { H18' } & -0.0900 & 0.9912 & 0.3093 & 0.050 \\ \text { C19' } & -0.1310(16) & 0.9655(15) & 0.2116(4) & 0.044(3) \\ \text { H19' } & -0.2807 & 1.0169 & 0.2038 & 0.052 \\ \text { C20' } & -0.0239(15) & 0.9052(11) & 0.1605(5) & 0.043(3) \\ \text { C21' } & 0.1951(16) & 0.8294(13) & 0.1707(5) & 0.041(3) \\ \text { H21' } & 0.2662 & 0.7886 & 0.1351 & 0.050 \\ \text { C22' } & 0.3081(16) & 0.8140(13) & 0.2331(5) & 0.035(3) \\ \text { H22' }^{\prime} & 0.4578 & 0.7624 & 0.2403 & 0.042\end{array}$

Table 5. Anisotropic atomic displacement parameters for $\mathrm{dwcm} 003 \mathrm{f}$

$\begin{array}{lllllll} & U_{11} & U_{22} & U_{33} & U_{12} & U_{13} & U_{23} \\ \text { Br1 } & 0.0435(14) & 0.087(4) & 0.035(2) & 0.000(2) & -0.0086(12) & 0.006(2) \\ \text { O1 } & 0.038(4) & 0.047(6) & 0.032(4) & -0.016(4) & 0.002(3) & -0.013(5) \\ \text { C2 } & 0.038(5) & 0.053(8) & 0.035(4) & -0.007(6) & -0.008(4) & -0.009(6) \\ \text { C3 } & 0.030(4) & 0.057(9) & 0.033(4) & -0.008(6) & -0.003(4) & -0.015(8) \\ \text { C3A } & 0.028(4) & 0.034(6) & 0.032(4) & -0.016(5) & -0.001(4) & -0.007(5) \\ \text { C4 } & 0.032(5) & 0.038(9) & 0.026(5) & -0.015(7) & -0.003(4) & -0.005(7) \\ \text { C5 } & 0.034(5) & 0.050(8) & 0.031(5) & -0.016(5) & -0.008(4) & 0.000(5) \\ \text { C6 } & 0.026(5) & 0.033(10) & 0.036(5) & -0.007(5) & -0.003(4) & -0.008(6) \\ \text { C7 } & 0.029(4) & 0.038(7) & 0.037(4) & -0.011(4) & 0.003(4) & -0.006(5) \\ \text { C7A } & 0.033(4) & 0.038(6) & 0.032(4) & -0.012(4) & 0.004(3) & -0.012(5) \\ \text { O8 } & 0.036(4) & 0.054(7) & 0.029(4) & -0.018(5) & -0.010(4) & -0.003(5) \\ \text { C9 } & 0.042(6) & 0.072(11) & 0.028(6) & -0.024(7) & -0.014(5) & 0.000(7) \\ \text { C10 } & 0.041(5) & 0.051(8) & 0.034(5) & 0.000(7) & -0.002(4) & 0.008(7) \\ \text { C11 } & 0.084(9) & 0.032(9) & 0.033(7) & -0.026(9) & 0.002(7) & -0.010(7) \\ \text { C12 } & 0.047(6) & 0.059(9) & 0.026(5) & 0.003(6) & -0.014(5) & -0.003(6) \\ \text { C13 } & 0.043(5) & 0.052(9) & 0.024(6) & -0.003(7) & -0.008(5) & -0.006(7) \\ \text { O14 } & 0.036(4) & 0.066(8) & 0.033(4) & 0.004(5) & -0.002(3) & 0.008(5)\end{array}$




\begin{tabular}{|c|c|c|c|c|c|c|}
\hline C15 & $0.036(5)$ & $0.049(8)$ & $0.039(5)$ & $-0.005(6)$ & 0.004 (4) & $0.010(6)$ \\
\hline O16 & $0.043(6)$ & 0.087 (11) & $0.031(5)$ & $0.012(6)$ & $0.005(5)$ & 0.007 (6) \\
\hline C17 & $0.025(4)$ & $0.037(8)$ & $0.033(4)$ & $-0.017(5)$ & $0.002(4)$ & $0.001(5)$ \\
\hline C18 & $0.033(4)$ & $0.044(8)$ & $0.043(5)$ & $-0.009(6)$ & $0.006(4)$ & $0.004(7)$ \\
\hline C19 & $0.025(4)$ & $0.044(8)$ & $0.047(4)$ & $-0.008(6)$ & $0.000(4)$ & $0.003(6)$ \\
\hline $\mathrm{C} 20$ & $0.035(5)$ & $0.051(8)$ & $0.034(5)$ & $-0.012(5)$ & $0.001(4)$ & $0.015(6)$ \\
\hline $\mathrm{C} 21$ & $0.032(4)$ & $0.040(8)$ & $0.030(4)$ & $-0.007(5)$ & $0.011(4)$ & $0.011(6)$ \\
\hline $\mathrm{C} 22$ & $0.030(5)$ & $0.047(8)$ & $0.035(5)$ & $-0.010(5)$ & 0.004 (4) & $0.008(6)$ \\
\hline Br1' & 0.053 (2) & $0.122(4)$ & $0.040(2)$ & $-0.006(2)$ & $-0.0018(13)$ & -0.001 \\
\hline O1' & $0.034(3)$ & $0.070(7)$ & $0.025(3)$ & $-0.012(5)$ & $0.010(3)$ & $-0.014(6)$ \\
\hline $\mathrm{C} 2^{\prime}$ & $0.031(5)$ & $0.060(9)$ & $0.031(4)$ & $-0.006(6)$ & $0.004(4)$ & $-0.014(6)$ \\
\hline C3' & $0.033(5)$ & & & & & $-0.017(6)$ \\
\hline C3A' & $0.027(4)$ & $0.062(8)$ & $0.028(4)$ & $-0.016(5)$ & 0.008 (4) & $-0.011(6)$ \\
\hline C4' & $0.015(5)$ & $0.056(11)$ & $0.028(5)$ & $-0.006(6)$ & $0.006(4)$ & $-0.006(7)$ \\
\hline C5' & $0.028(5)$ & $0.083(9)$ & $0.030(4)$ & $-0.020(6)$ & $0.012(4)$ & $-0.006(7)$ \\
\hline C6' & $0.024(5)$ & 0.062 (14) & $0.035(5)$ & $-0.011(6)$ & $-0.004(4)$ & $-0.011(6)$ \\
\hline $\mathrm{C}^{\prime}$ & $0.031(4)$ & $0.060(8)$ & $0.031(4)$ & $-0.014(5)$ & $0.015(4)$ & $-0.013(5)$ \\
\hline $\mathrm{C}^{\prime} \mathrm{A}^{\prime}$ & $0.030(3)$ & $0.065(7)$ & $0.025(3)$ & $-0.014(5)$ & $0.012(3)$ & $-0.011(5)$ \\
\hline O8' & $0.031(4)$ & $0.085(9)$ & $0.031(4)$ & $-0.024(6)$ & 0.007 (3) & $-0.004(6)$ \\
\hline C9' & $0.045(6)$ & $0.065(10)$ & $0.030(6)$ & $-0.028(7)$ & $0.016(5)$ & $-0.002(7)$ \\
\hline C10' & $0.041(5)$ & $0.066(9)$ & $0.030(5)$ & & & $-0.005(6)$ \\
\hline C11' & $0.120(12)$ & $0.060(11)$ & $0.041(8)$ & 0.000 (13) & 0.007 (10) & $-0.016(8)$ \\
\hline C12' & $0.040(6)$ & $0.075(10)$ & $0.029(6)$ & $0.001(8)$ & $0.014(5)$ & $-0.003(6)$ \\
\hline C13' & $0.043(5)$ & $0.078(9)$ & $0.028(6)$ & $0.007(7)$ & $0.003(4)$ & $0.000(7)$ \\
\hline O14' & 0.038 (4) & $0.080(9)$ & $0.031(4)$ & $0.005(5)$ & $0.006(3)$ & $-0.002(5)$ \\
\hline $\mathrm{C} 15^{\prime}$ & 0.035 (4) & $0.077(9)$ & $0.038(4)$ & $0.004(7)$ & 0.007 (4) & $0.001(7)$ \\
\hline O16' & $0.047(6)$ & $0.137(15)$ & $0.038(5)$ & $0.015(9)$ & $0.012(5)$ & $-0.014(9)$ \\
\hline C17' & $0.028(4)$ & $0.052(7)$ & $0.033(4)$ & $-0.015(6)$ & 0.007 (3) & $0.003(6)$ \\
\hline C18' & $0.034(5)$ & $0.058(9)$ & $0.035(5)$ & $-0.005(6)$ & $0.016(4)$ & $0.005(6)$ \\
\hline C19' & $0.028(5)$ & $0.055(8)$ & $0.047(5)$ & $-0.009(5)$ & $0.002(4)$ & $0.009(6)$ \\
\hline C20' & $0.041(5)$ & $0.054(7)$ & $0.034(4)$ & $-0.006(6)$ & $0.002(4)$ & $0.005(6)$ \\
\hline C21' & $0.042(4)$ & $0.052(9)$ & $0.031(4)$ & $-0.011(5)$ & 0.008 (4) & 0.009 (6) \\
\hline $\mathrm{C} 22^{\prime}$ & $0.023(4)$ & $0.046(9)$ & 0.037 (4) & $-0.014(5)$ & 0.007 (4) & $0.005(5)$ \\
\hline
\end{tabular}

Table 6. Geometric parameters $\left(\AA,^{\circ}\right)$ for dwcm003f

$\begin{array}{llll}\mathrm{Br} 1-\mathrm{C} 20 & 1.890(7) & \mathrm{Br} 11^{\prime}-\mathrm{C}^{2} 0^{\prime} & 1.889(7) \\ \mathrm{O} 1-\mathrm{C} 7 \mathrm{~A} & 1.374(7) & \mathrm{O} 1^{\prime}-\mathrm{C}^{\prime} \mathrm{A}^{\prime} & 1.374(7) \\ \mathrm{O} 1-\mathrm{C} 2 & 1.404(7) & \mathrm{O} 1^{\prime}-\mathrm{C} 2^{\prime} & 1.401(7) \\ \mathrm{C} 2-\mathrm{C} 3 & 1.337(8) & \mathrm{C} 2^{\prime}-\mathrm{C} 3^{\prime} & 1.340(8) \\ \mathrm{C} 2-\mathrm{C} 10 & 1.473(8) & \mathrm{C} 2^{\prime}-\mathrm{C} 10^{\prime} & 1.474(8)\end{array}$




\begin{tabular}{|c|c|c|c|}
\hline $\mathrm{C} 3-\mathrm{C} 3 \mathrm{~A}$ & $1.437(8)$ & $\mathrm{C} 3^{\prime}-\mathrm{C} 3 \mathrm{~A}^{\prime}$ & 1.437 (8) \\
\hline $\mathrm{C} 3 \mathrm{~A}-\mathrm{C} 7 \mathrm{~A}$ & $1.397(7)$ & $\mathrm{C} 3 \mathrm{~A}^{\prime}-\mathrm{C}^{\prime} \mathrm{A}^{\prime}$ & $1.393(7)$ \\
\hline $\mathrm{C} 3 \mathrm{~A}-\mathrm{C} 4$ & $1.397(8)$ & $\mathrm{C} 3 \mathrm{~A}^{\prime}-\mathrm{C} 4^{\prime}$ & $1.398(7)$ \\
\hline $\mathrm{C} 4-\mathrm{C} 5$ & $1.362(8)$ & $\mathrm{C} 4^{\prime}-\mathrm{C} 5^{\prime}$ & $1.363(8)$ \\
\hline $\mathrm{C} 5-\mathrm{O} 8$ & $1.379(7)$ & $\mathrm{C}^{\prime}-\mathrm{O} 8^{\prime}$ & $1.380(7)$ \\
\hline $\mathrm{C} 5-\mathrm{C} 6$ & $1.399(8)$ & $\mathrm{C}^{\prime}-\mathrm{C} 6^{\prime}$ & $1.394(8)$ \\
\hline $\mathrm{C} 6-\mathrm{C} 7$ & $1.390(8)$ & $\mathrm{C} 6^{\prime}-\mathrm{C} 7^{\prime}$ & $1.395(8)$ \\
\hline C7-C7A & $1.379(8)$ & $\mathrm{C}^{\prime}-\mathrm{C} 7 \mathrm{~A}^{\prime}$ & $1.379(8)$ \\
\hline $\mathrm{O} 8-\mathrm{C} 9$ & $1.430(7)$ & $\mathrm{O} 8^{\prime}-\mathrm{C} 9^{\prime}$ & $1.434(7)$ \\
\hline $\mathrm{C} 10-\mathrm{C} 11$ & $1.488(12)$ & $\mathrm{C} 10^{\prime}-\mathrm{C} 11^{\prime}$ & $1.492(12)$ \\
\hline $\mathrm{C} 10-\mathrm{C} 12$ & $1.558(11)$ & $\mathrm{C} 10^{\prime}-\mathrm{C} 12^{\prime}$ & $1.554(11)$ \\
\hline $\mathrm{C} 12-\mathrm{C} 13$ & $1.506(13)$ & $\mathrm{C} 12^{\prime}-\mathrm{C} 13^{\prime}$ & 1.499 (13) \\
\hline $\mathrm{C} 13-\mathrm{O} 14$ & $1.466(8)$ & $\mathrm{C} 13^{\prime}-\mathrm{O} 14^{\prime}$ & $1.463(8)$ \\
\hline $\mathrm{O} 14-\mathrm{C} 15$ & $1.350(8)$ & $\mathrm{O} 14^{\prime}-\mathrm{C} 15^{\prime}$ & $1.348(7)$ \\
\hline $\mathrm{C} 15-\mathrm{O} 16$ & $1.209(7)$ & $\mathrm{C} 15^{\prime}-\mathrm{O} 16^{\prime}$ & $1.207(7)$ \\
\hline $\mathrm{C} 15-\mathrm{C} 17$ & $1.486(8)$ & $\mathrm{C} 15^{\prime}-\mathrm{C} 17^{\prime}$ & $1.489(8)$ \\
\hline $\mathrm{C} 17-\mathrm{C} 22$ & $1.391(9)$ & $\mathrm{C} 17^{\prime}-\mathrm{C} 22^{\prime}$ & $1.390(9)$ \\
\hline $\mathrm{C} 17-\mathrm{C} 18$ & $1.413(8)$ & $\mathrm{C} 17^{\prime}-\mathrm{C} 18^{\prime}$ & $1.413(8)$ \\
\hline $\mathrm{C} 18-\mathrm{C} 19$ & $1.383(8)$ & $\mathrm{C} 18^{\prime}-\mathrm{C} 19^{\prime}$ & $1.381(8)$ \\
\hline $\mathrm{C} 19-\mathrm{C} 20$ & $1.381(8)$ & $\mathrm{C} 19^{\prime}-\mathrm{C} 20^{\prime}$ & $1.382(8)$ \\
\hline $\mathrm{C} 20-\mathrm{C} 21$ & $1.392(8)$ & $\mathrm{C} 20^{\prime}-\mathrm{C} 21^{\prime}$ & $1.391(8)$ \\
\hline $\mathrm{C} 21-\mathrm{C} 22$ & $1.380(9)$ & $\mathrm{C} 21^{\prime}-\mathrm{C} 22^{\prime}$ & $1.381(9)$ \\
\hline
\end{tabular}

$\begin{array}{ll}\mathrm{C} 7 \mathrm{~A}-\mathrm{O} 1-\mathrm{C} 2 & 105.5(5) \\ \mathrm{C} 3-\mathrm{C} 2-\mathrm{O} 1 & 110.3(5) \\ \mathrm{C} 3-\mathrm{C} 2-\mathrm{C} 10 & 134.8(7) \\ \mathrm{O} 1-\mathrm{C} 2-\mathrm{C} 10 & 114.9(6) \\ \mathrm{C} 2-\mathrm{C} 3-\mathrm{C} 3 \mathrm{~A} & 108.8(5) \\ \mathrm{C} 7 \mathrm{~A}-\mathrm{C} 3 \mathrm{~A}-\mathrm{C} 4 & 119.6(6) \\ \mathrm{C} 7 \mathrm{~A}-\mathrm{C} 3 \mathrm{~A}-\mathrm{C} 3 & 104.1(5) \\ \mathrm{C} 4-\mathrm{C} 3 \mathrm{~A}-\mathrm{C} 3 & 136.3(6) \\ \mathrm{C} 5-\mathrm{C} 4-\mathrm{C} 3 \mathrm{~A} & 118.4(6) \\ \mathrm{C} 4-\mathrm{C} 5-\mathrm{O} 8 & 126.3(6) \\ \mathrm{C} 4-\mathrm{C} 5-\mathrm{C} 6 & 122.0(6) \\ \mathrm{O} 8-\mathrm{C} 5-\mathrm{C} 6 & 111.7(6) \\ \mathrm{C} 7-\mathrm{C} 6-\mathrm{C} 5 & 120.3(6) \\ \mathrm{C} 7 \mathrm{~A}-\mathrm{C} 7-\mathrm{C} 6 & 117.6(6) \\ \mathrm{O} 1-\mathrm{C} 7 \mathrm{~A}-\mathrm{C} 7 & 126.5(6) \\ \mathrm{O} 1-\mathrm{C} 7 \mathrm{~A}-\mathrm{C} 3 \mathrm{~A} & 111.3(5) \\ \mathrm{C} 7-\mathrm{C} 7 \mathrm{~A}-\mathrm{C} 3 \mathrm{~A} & 122.2(6) \\ \mathrm{C} 5-\mathrm{O} 8-\mathrm{C} 9 & 117.2(6)\end{array}$

\begin{tabular}{|c|c|}
\hline $\mathrm{C}^{\prime} \mathrm{A}^{\prime}-\mathrm{O} 1^{\prime}-\mathrm{C} 2^{\prime}$ & $105.6(5)$ \\
\hline $\mathrm{C} 3^{\prime}-\mathrm{C} 2^{\prime}-\mathrm{O} 1^{\prime}$ & $110.2(5)$ \\
\hline $\mathrm{C}^{\prime}{ }^{\prime}-\mathrm{C} 2^{\prime}-\mathrm{C} 10^{\prime}$ & $134.3(6)$ \\
\hline $\mathrm{O} 1^{\prime}-\mathrm{C} 2^{\prime}-\mathrm{C} 10^{\prime}$ & $115.5(6)$ \\
\hline $\mathrm{C} 2^{\prime}-\mathrm{C} 3^{\prime}-\mathrm{C} 3 \mathrm{~A}^{\prime}$ & $108.7(5)$ \\
\hline $\mathrm{C} 7 \mathrm{~A}^{\prime}-\mathrm{C} 3 \mathrm{~A}^{\prime}-\mathrm{C} 4^{\prime}$ & $119.7(5)$ \\
\hline $\mathrm{C}^{\prime} \mathrm{A}^{\prime}-\mathrm{C} 3 \mathrm{~A}^{\prime}-\mathrm{C} 3^{\prime}$ & $104.3(5)$ \\
\hline $\mathrm{C} 4^{\prime}-\mathrm{C} 3 \mathrm{~A}^{\prime}-\mathrm{C} 3^{\prime}$ & $136.0(6)$ \\
\hline $\mathrm{C} 5^{\prime}-\mathrm{C} 4^{\prime}-\mathrm{C} 3 \mathrm{~A}^{\prime}$ & $118.1(6)$ \\
\hline $\mathrm{C}^{\prime}-\mathrm{C} 5^{\prime}-\mathrm{O} 8^{\prime}$ & $125.7(6)$ \\
\hline $\mathrm{C} 4^{\prime}-\mathrm{C} 5^{\prime}-\mathrm{C} 6^{\prime}$ & $122.2(6)$ \\
\hline $\mathrm{O} 8^{\prime}-\mathrm{C} 5^{\prime}-\mathrm{C}^{\prime}$ & $112.2(6)$ \\
\hline $\mathrm{C}^{\prime}-\mathrm{C} 6^{\prime}-\mathrm{C} 7^{\prime}$ & $120.3(6)$ \\
\hline $\mathrm{C}^{7} \mathrm{~A}^{\prime}-\mathrm{C} 7^{\prime}-\mathrm{C} 6^{\prime}$ & $117.3(6)$ \\
\hline $\mathrm{O} 1^{\prime}-\mathrm{C} 7 \mathrm{~A}^{\prime}-\mathrm{C}^{\prime}$ & $126.4(6)$ \\
\hline $\mathrm{O} 1^{\prime}-\mathrm{C} 7 \mathrm{~A}^{\prime}-\mathrm{C} 3 \mathrm{~A}^{\prime}$ & $111.3(5)$ \\
\hline $\mathrm{C}^{\prime}-\mathrm{C} 7 \mathrm{~A}^{\prime}-\mathrm{C} 3 \mathrm{~A}^{\prime}$ & $122.3(6)$ \\
\hline $\mathrm{C}^{\prime}-\mathrm{O} 8^{\prime}-\mathrm{C} 9^{\prime}$ & $116.7(6)$ \\
\hline
\end{tabular}




$\begin{array}{llll}\mathrm{C} 2-\mathrm{C} 10-\mathrm{C} 11 & 111.9(6) & \mathrm{C} 2{ }^{\prime}-\mathrm{C} 10^{\prime}-\mathrm{C} 11^{\prime} & 111.3(7) \\ \mathrm{C} 2-\mathrm{C} 10-\mathrm{C} 12 & 114.3(6) & \mathrm{C} 2{ }^{\prime}-\mathrm{C} 10^{\prime}-\mathrm{C} 12^{\prime} & 114.9(6) \\ \mathrm{C} 11-\mathrm{C} 10-\mathrm{C} 12 & 108.6(8) & \mathrm{C} 11^{\prime}-\mathrm{C} 10^{\prime}-\mathrm{C} 12^{\prime} & 108.5(8) \\ \mathrm{C} 13-\mathrm{C} 12-\mathrm{C} 10 & 112.7(8) & \mathrm{C} 13^{\prime}-\mathrm{C} 12^{\prime}-\mathrm{C} 10^{\prime} & 113.5(8) \\ \mathrm{O} 14-\mathrm{C} 13-\mathrm{C} 12 & 111.6(8) & \mathrm{O} 14^{\prime}-\mathrm{C} 13^{\prime}-\mathrm{C} 12^{\prime} & 112.0(9) \\ \mathrm{C} 15-\mathrm{O} 14-\mathrm{C} 13 & 117.3(7) & \mathrm{C} 15^{\prime}-\mathrm{O} 14^{\prime}-\mathrm{C} 13^{\prime} & 117.8(7) \\ \mathrm{O} 16-\mathrm{C} 15-\mathrm{O} 14 & 124.2(7) & \mathrm{O} 16^{\prime}-\mathrm{C} 15^{\prime}-\mathrm{O} 14^{\prime} & 124.6(7) \\ \mathrm{O} 16-\mathrm{C} 15-\mathrm{C} 17 & 124.6(7) & \mathrm{O} 16^{\prime}-\mathrm{C} 15^{\prime}-\mathrm{C} 17^{\prime} & 124.4(7) \\ \mathrm{O} 14-\mathrm{C} 15-\mathrm{C} 17 & 111.2(6) & \mathrm{O} 14^{\prime}-\mathrm{C} 15^{\prime}-\mathrm{C} 17^{\prime} & 111.0(6) \\ \mathrm{C} 22-\mathrm{C} 17-\mathrm{C} 18 & 119.1(6) & \mathrm{C} 22^{\prime}-\mathrm{C} 17^{\prime}-\mathrm{C} 18^{\prime} & 119.3(6) \\ \mathrm{C} 22-\mathrm{C} 17-\mathrm{C} 15 & 123.5(6) & \mathrm{C} 22^{\prime}-\mathrm{C} 17^{\prime}-\mathrm{C} 15^{\prime} & 123.7(6) \\ \mathrm{C} 18-\mathrm{C} 17-\mathrm{C} 15 & 117.4(6) & \mathrm{C} 18^{\prime}-\mathrm{C} 17^{\prime}-\mathrm{C} 15^{\prime} & 117.1(6) \\ \mathrm{C} 19-\mathrm{C} 18-\mathrm{C} 17 & 120.2(6) & \mathrm{C} 19^{\prime}-\mathrm{C} 18^{\prime}-\mathrm{C} 17^{\prime} & 120.2(6) \\ \mathrm{C} 20-\mathrm{C} 19-\mathrm{C} 18 & 119.4(6) & \mathrm{C} 18^{\prime}-\mathrm{C} 19^{\prime}-\mathrm{C} 20^{\prime} & 119.3(6) \\ \mathrm{C} 19-\mathrm{C} 20-\mathrm{C} 21 & 121.4(6) & \mathrm{C} 19^{\prime}-\mathrm{C} 20^{\prime}-\mathrm{C} 21^{\prime} & 121.5(6) \\ \mathrm{C} 19-\mathrm{C} 20-\mathrm{B} 1 & 119.0(5) & \mathrm{C} 19^{\prime}-\mathrm{C} 20^{\prime}-\mathrm{Br} 1^{\prime} & 118.7(5) \\ \mathrm{C} 21-\mathrm{C} 20-\mathrm{B} 1 & 119.6(6) & \mathrm{C} 21^{\prime}-\mathrm{C} 20^{\prime}-\mathrm{B} 1^{\prime} & 119.8(6) \\ \mathrm{C} 22-\mathrm{C} 21-\mathrm{C} 20 & 119.2(6) & \mathrm{C} 22^{\prime}-\mathrm{C} 21^{\prime}-\mathrm{C} 20^{\prime} & 119.3(7) \\ \mathrm{C} 21-\mathrm{C} 22-\mathrm{C} 17 & 120.7(6) & \mathrm{C} 21^{\prime}-\mathrm{C} 22^{\prime}-\mathrm{C} 17^{\prime} & 120.6(6)\end{array}$

\section{Computer programs}

Data collection: COLLECT. ${ }^{8}$ Cell refinement: DENZO-SMN. ${ }^{9}$ Data reduction: DENZO-SMN. ${ }^{9}$ Program(s) used to solve structure: Siemens SHELXTL. ${ }^{10}$ Program(s) used to refine structure: Siemens SHELXTL. ${ }^{10}$ Molecular graphics: Siemens SHELXTL. ${ }^{10}$ Software used to prepare material for publication: Siemens SHELXTL, ${ }^{10}$ publCIF ${ }^{15}$ printCIF for Word. ${ }^{16}$

(15) Westrip, S. P. publCIF, version 1.0c; International Union of Crystallography, Abbey Square: Chester, U. K., 2006.

(16) prinfCIF for word; International Union of Crystallography, Abbey Square: Chester, U. K., 2005. 


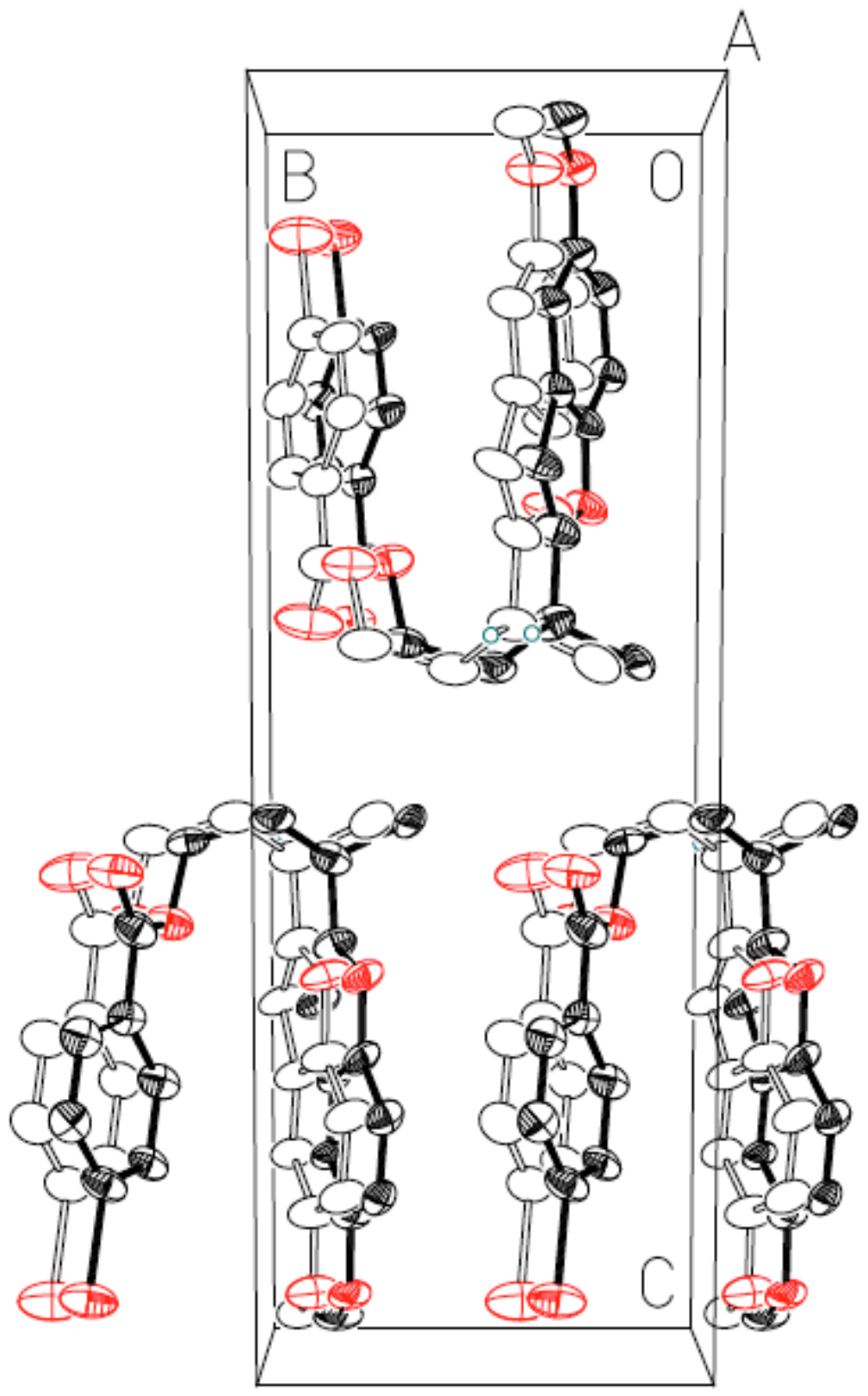




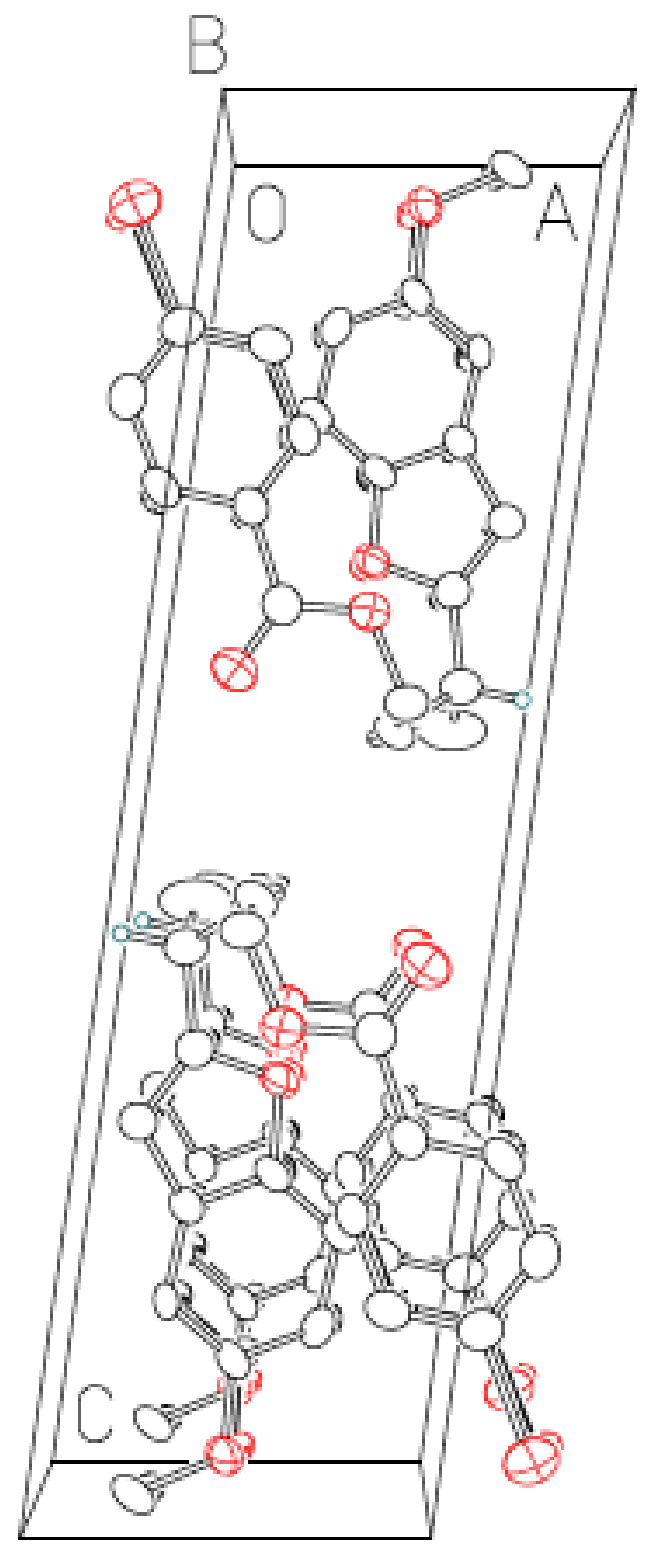




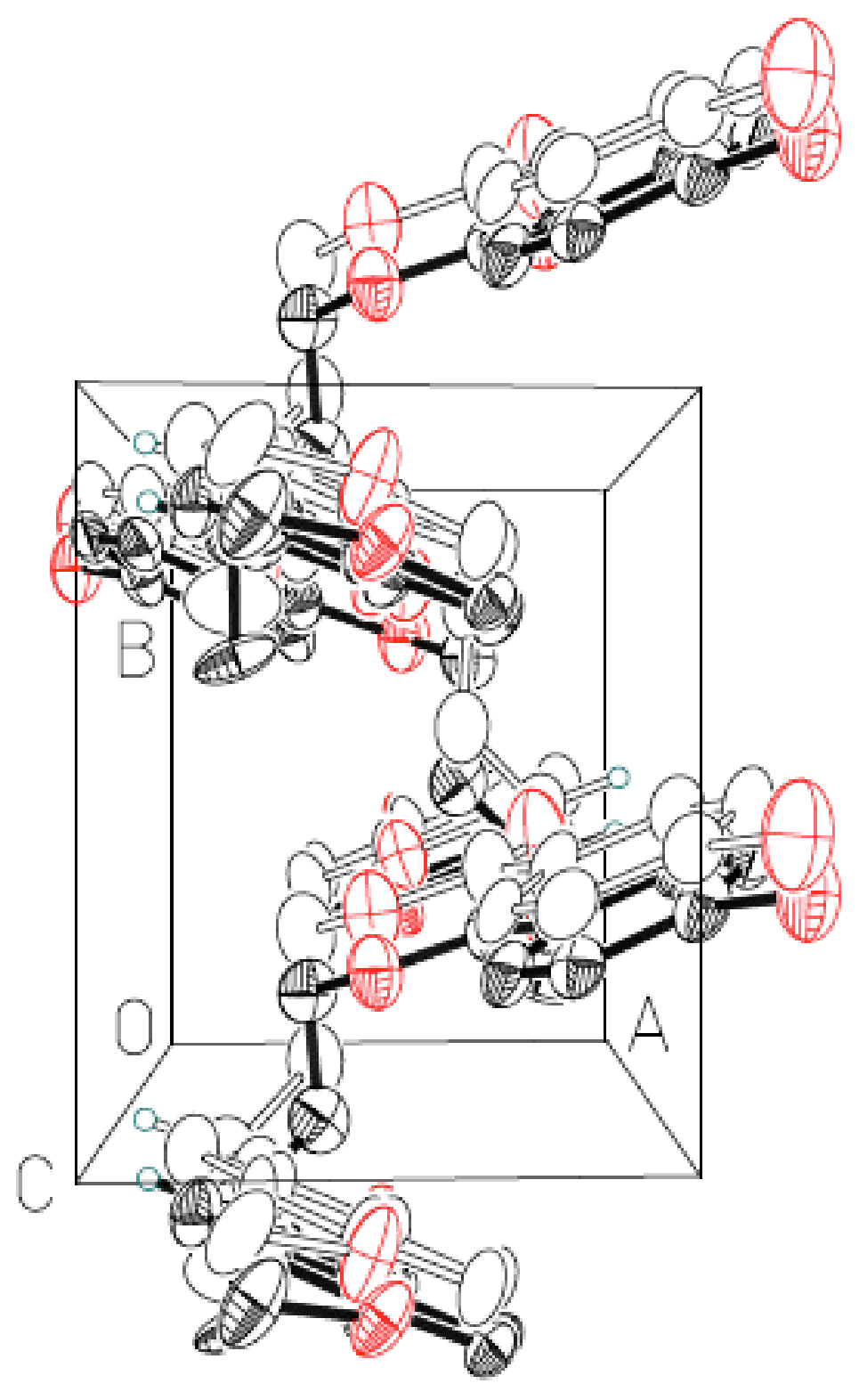




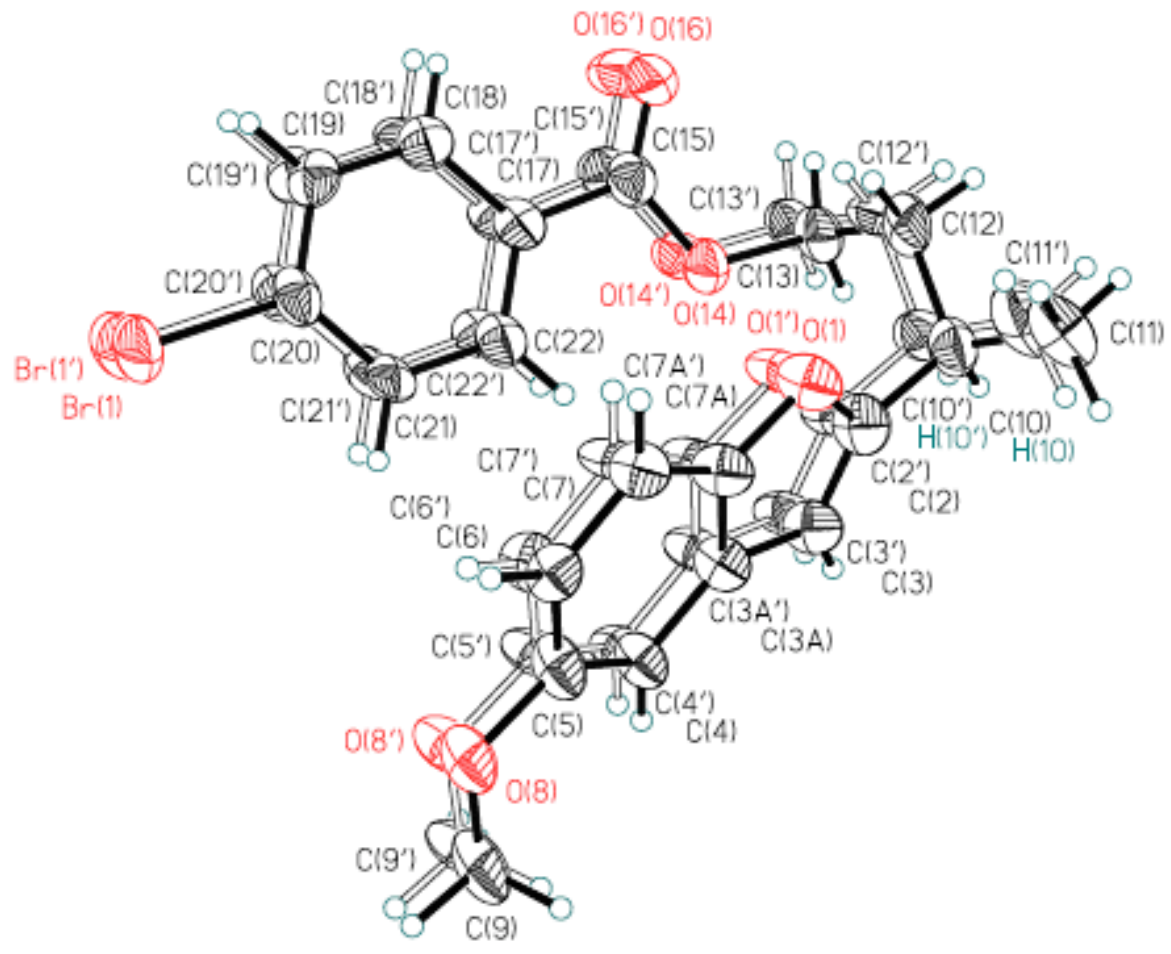



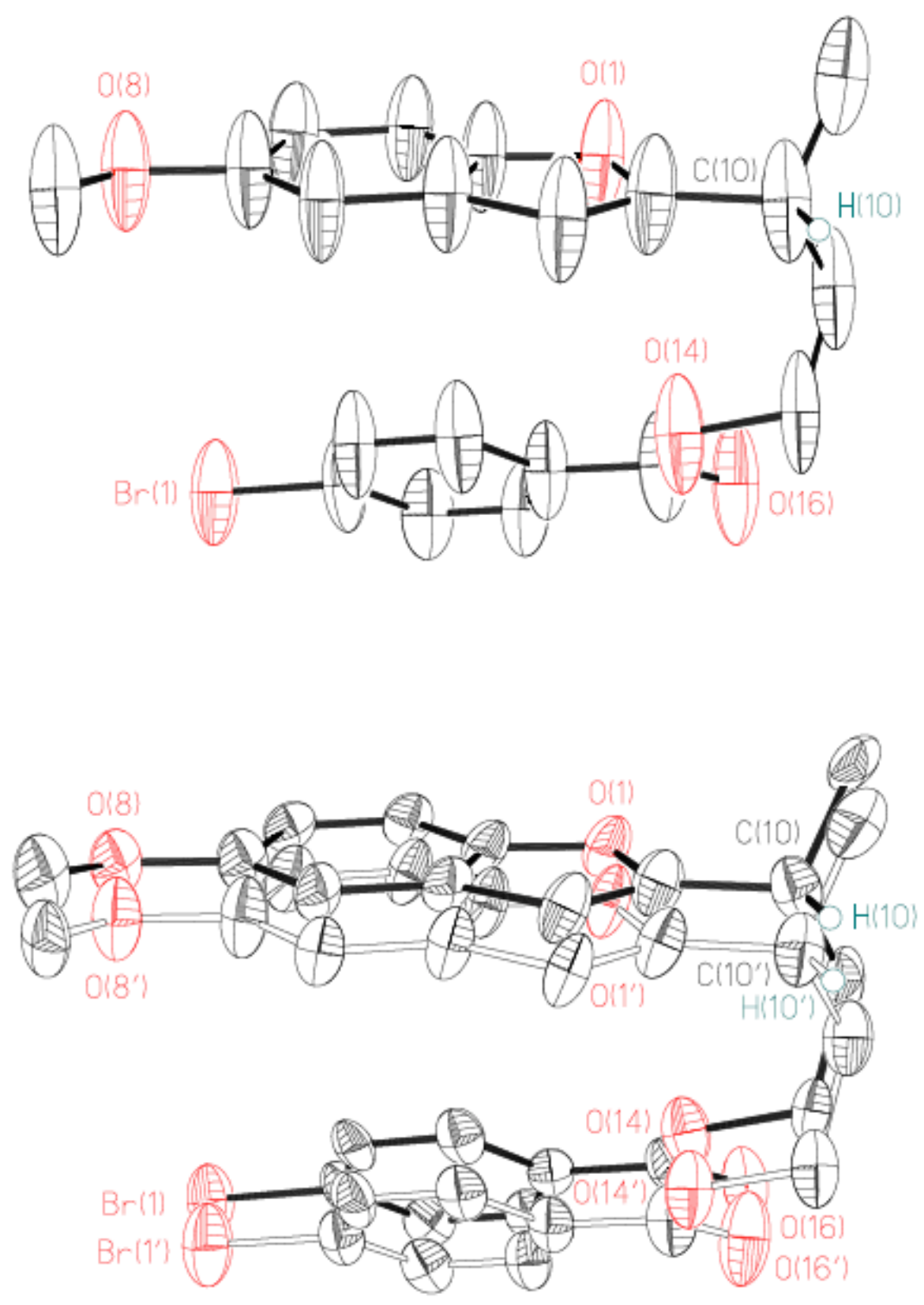


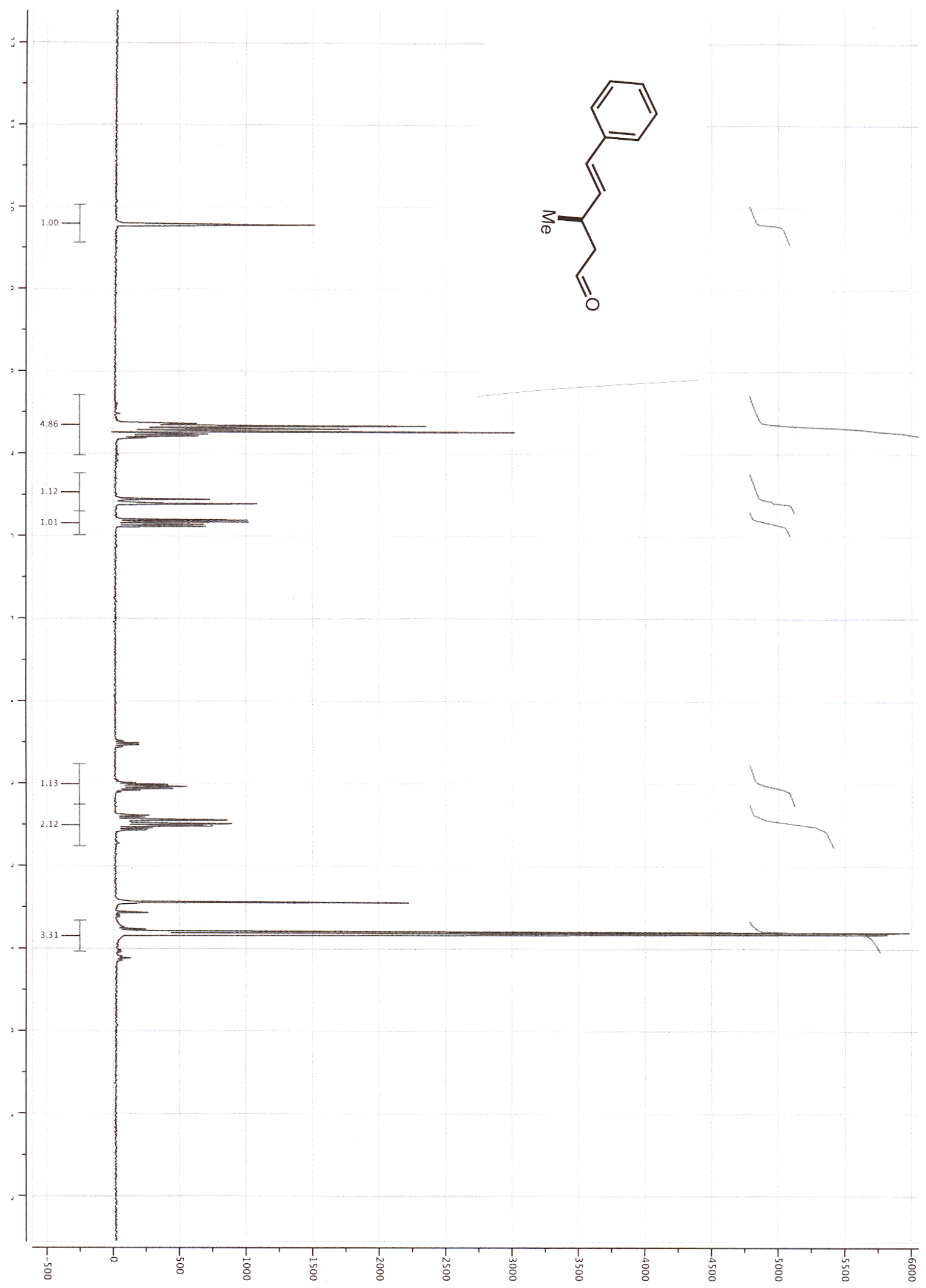




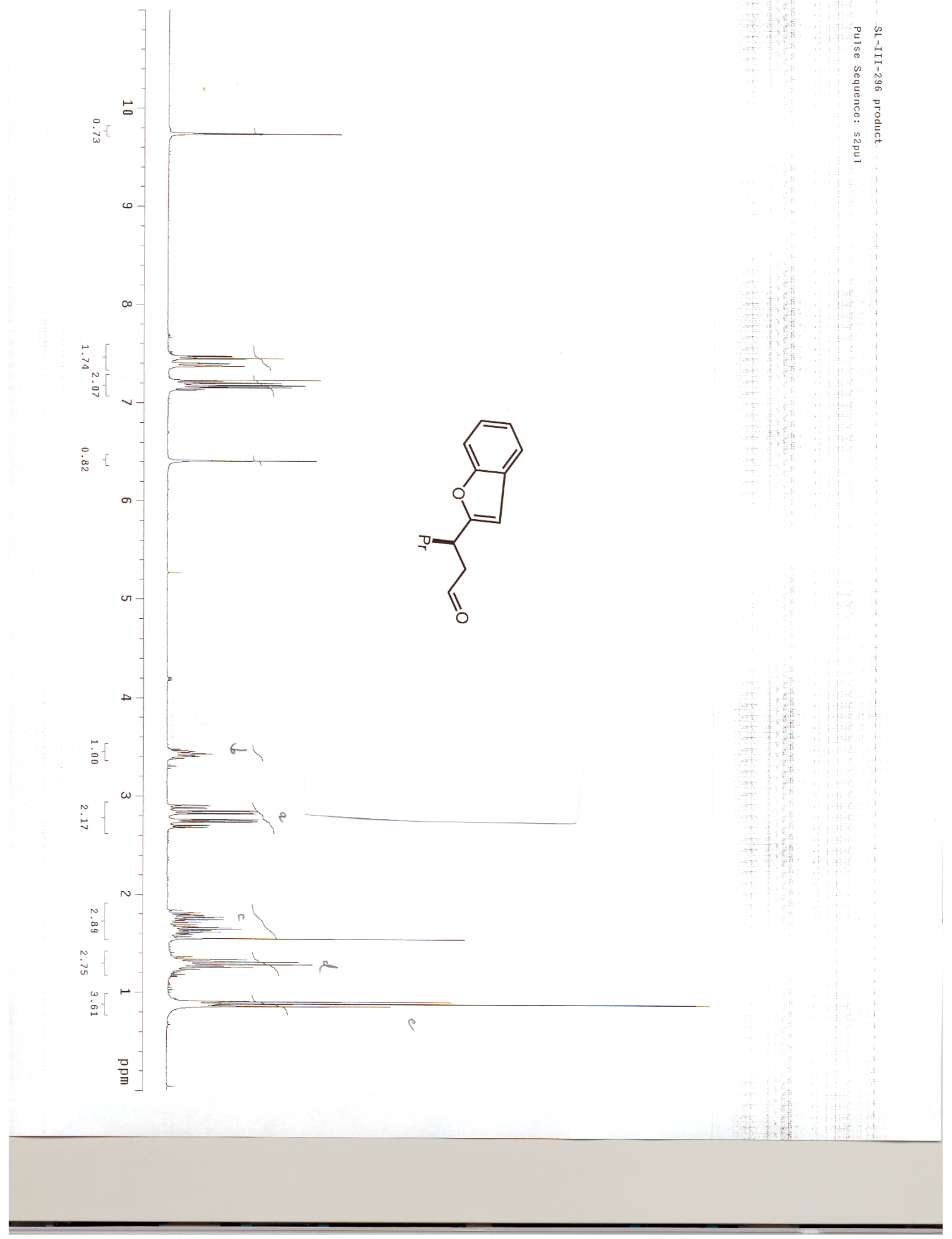




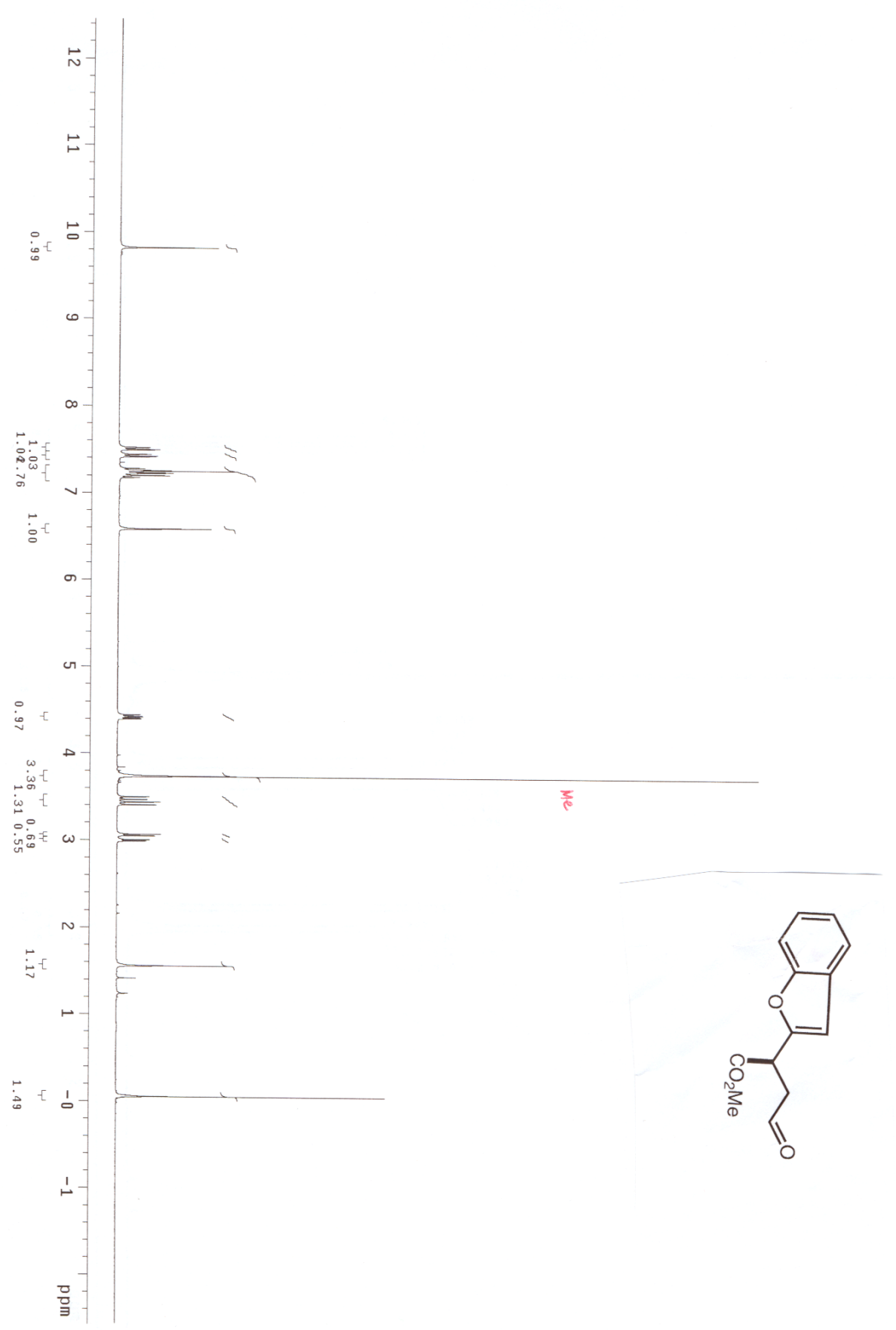



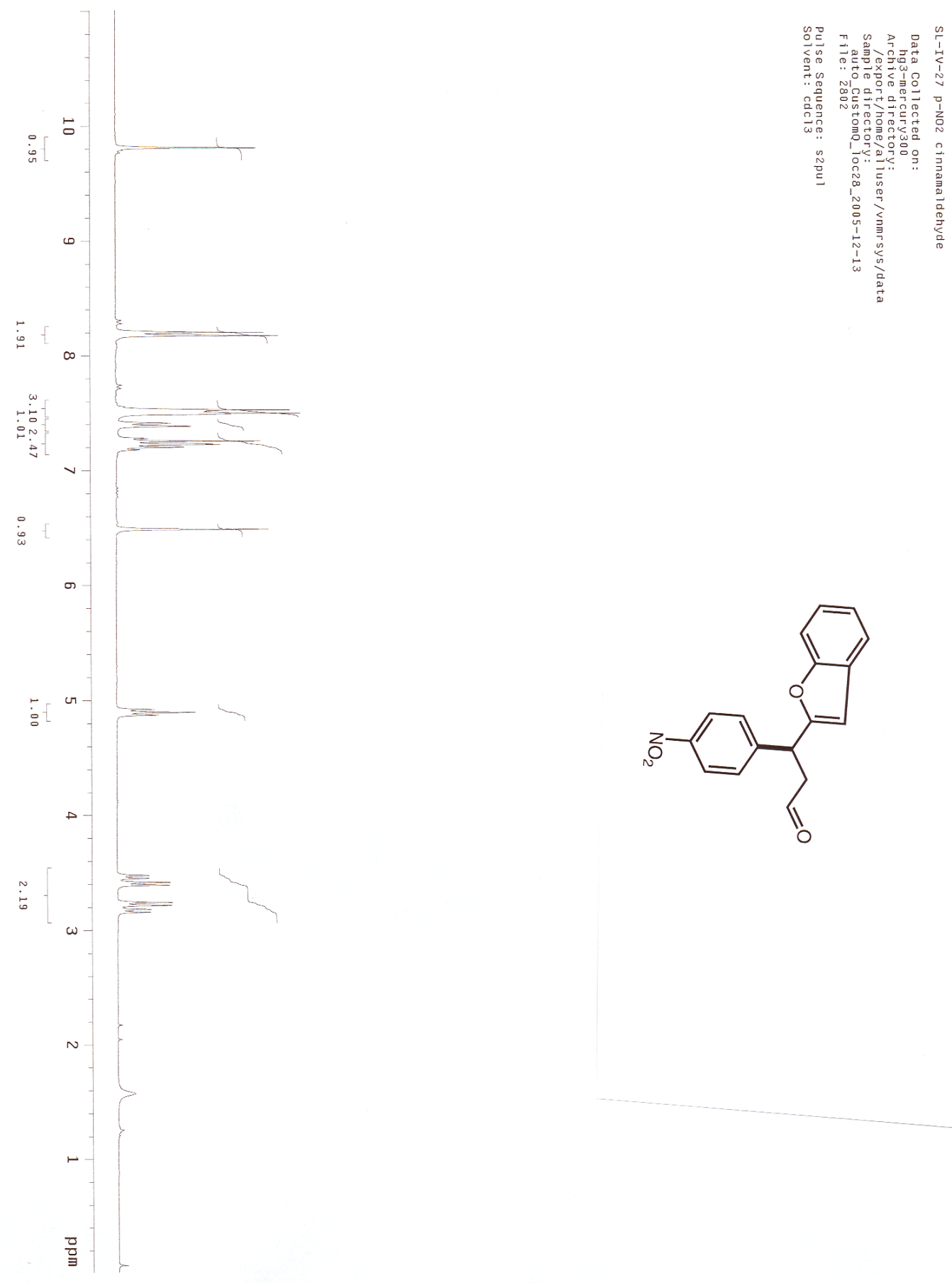


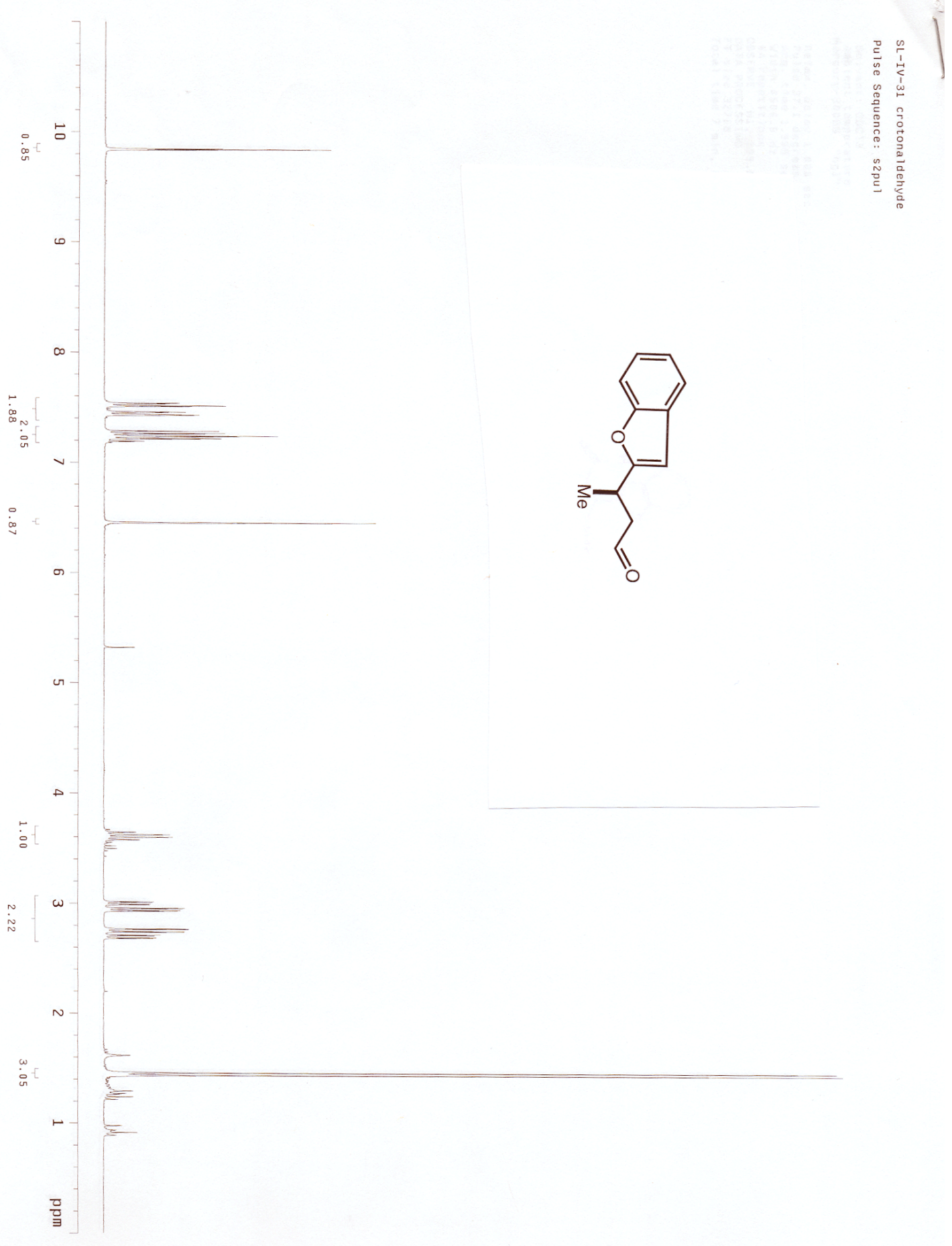




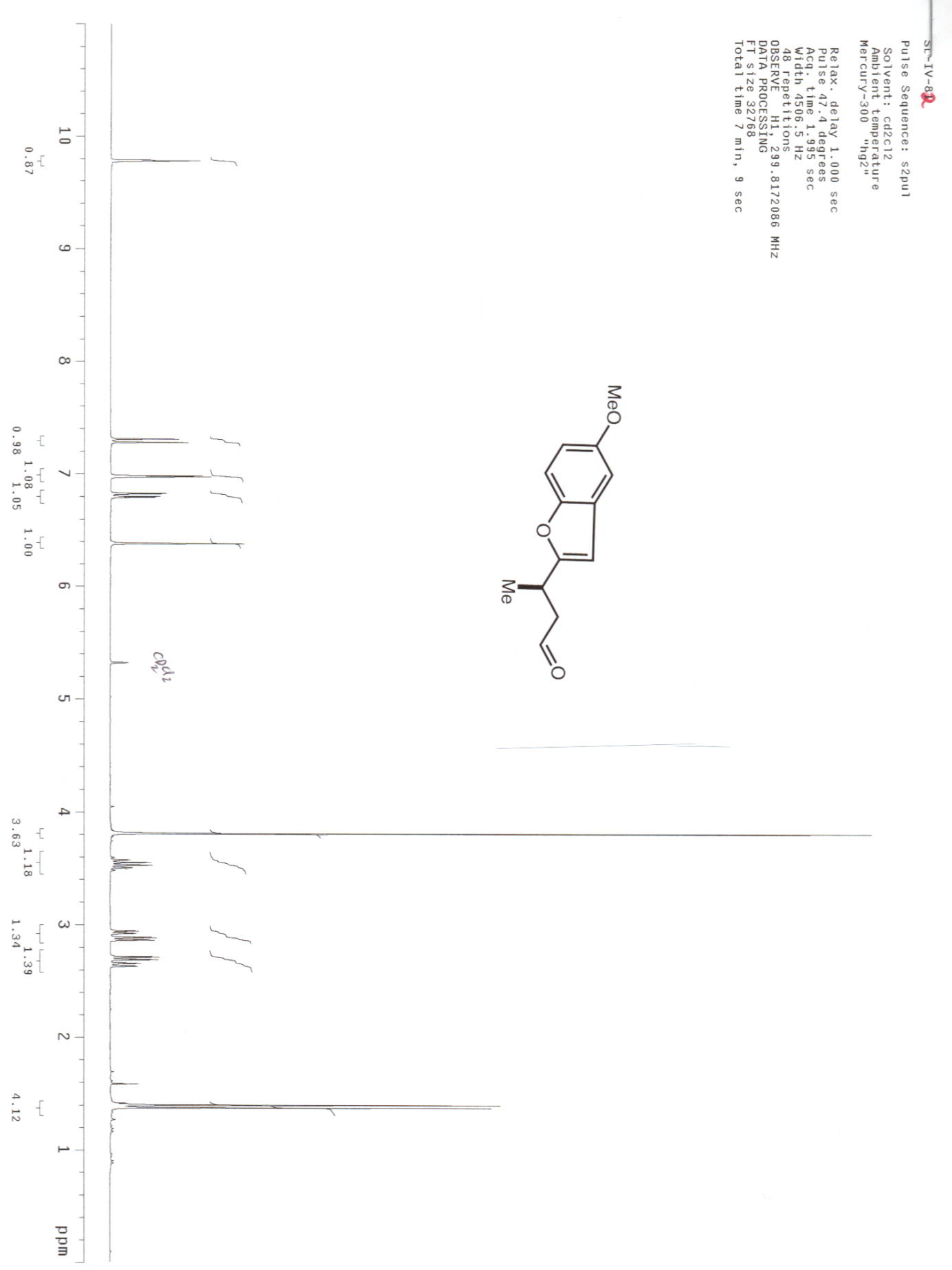



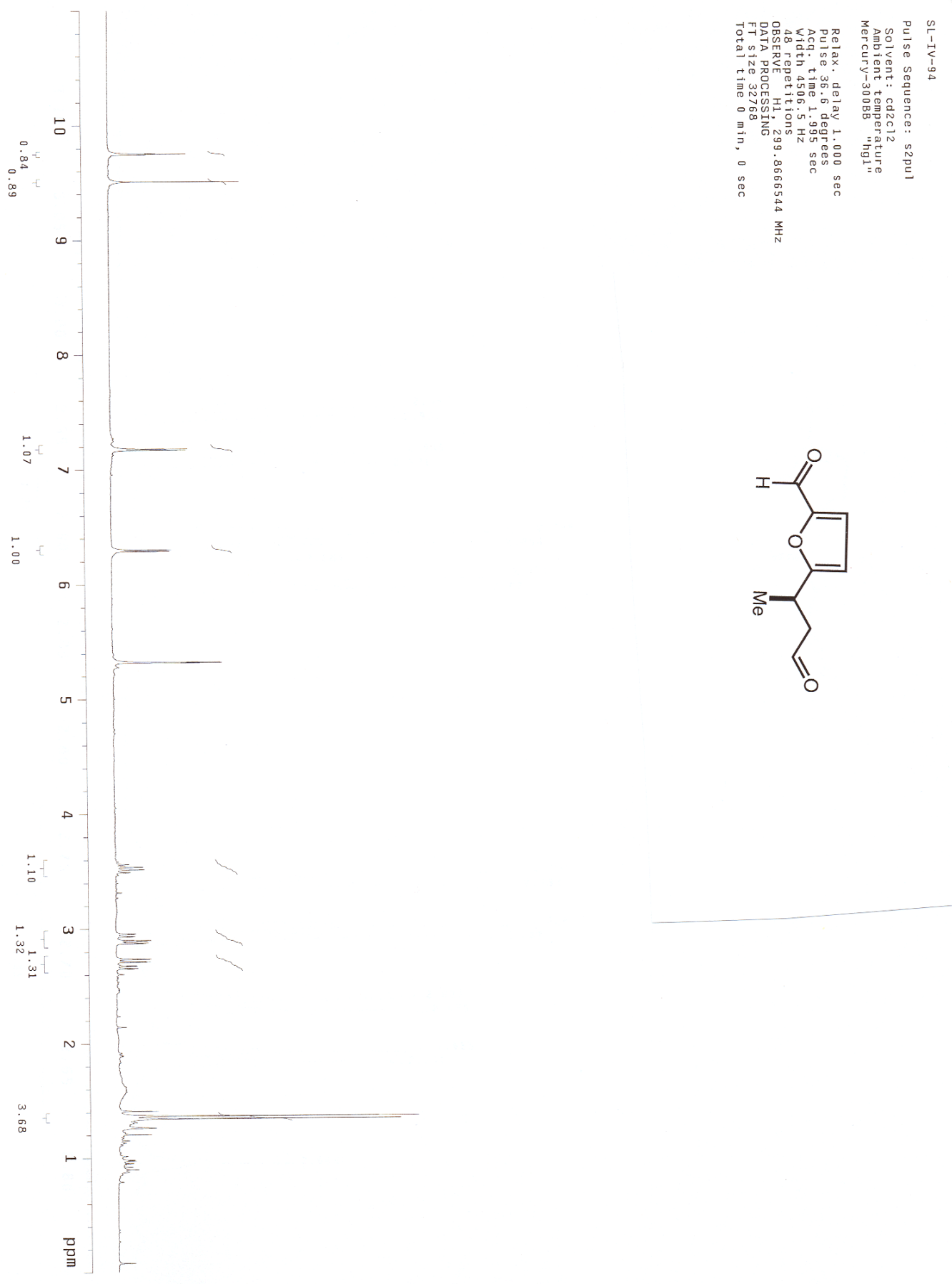

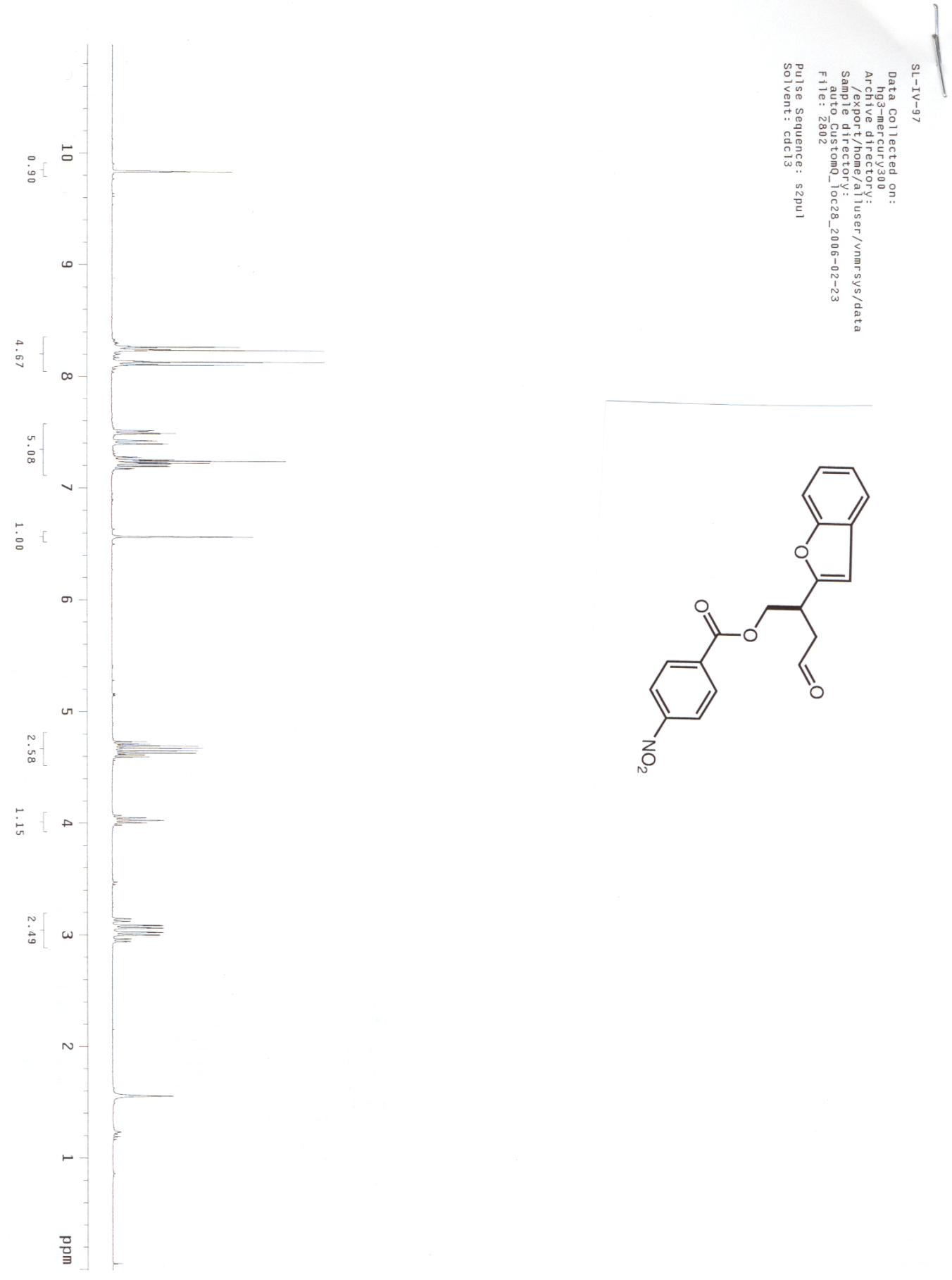


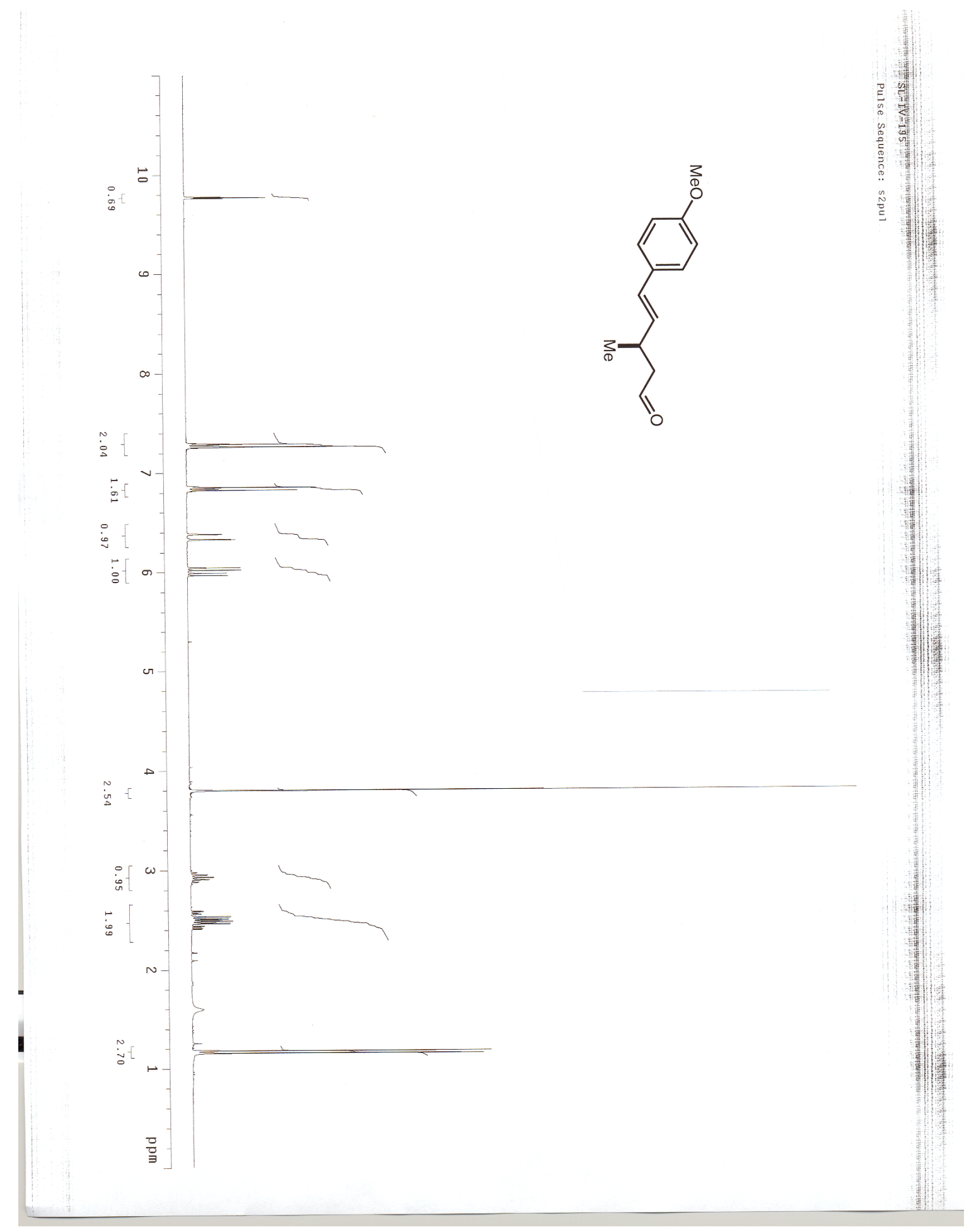




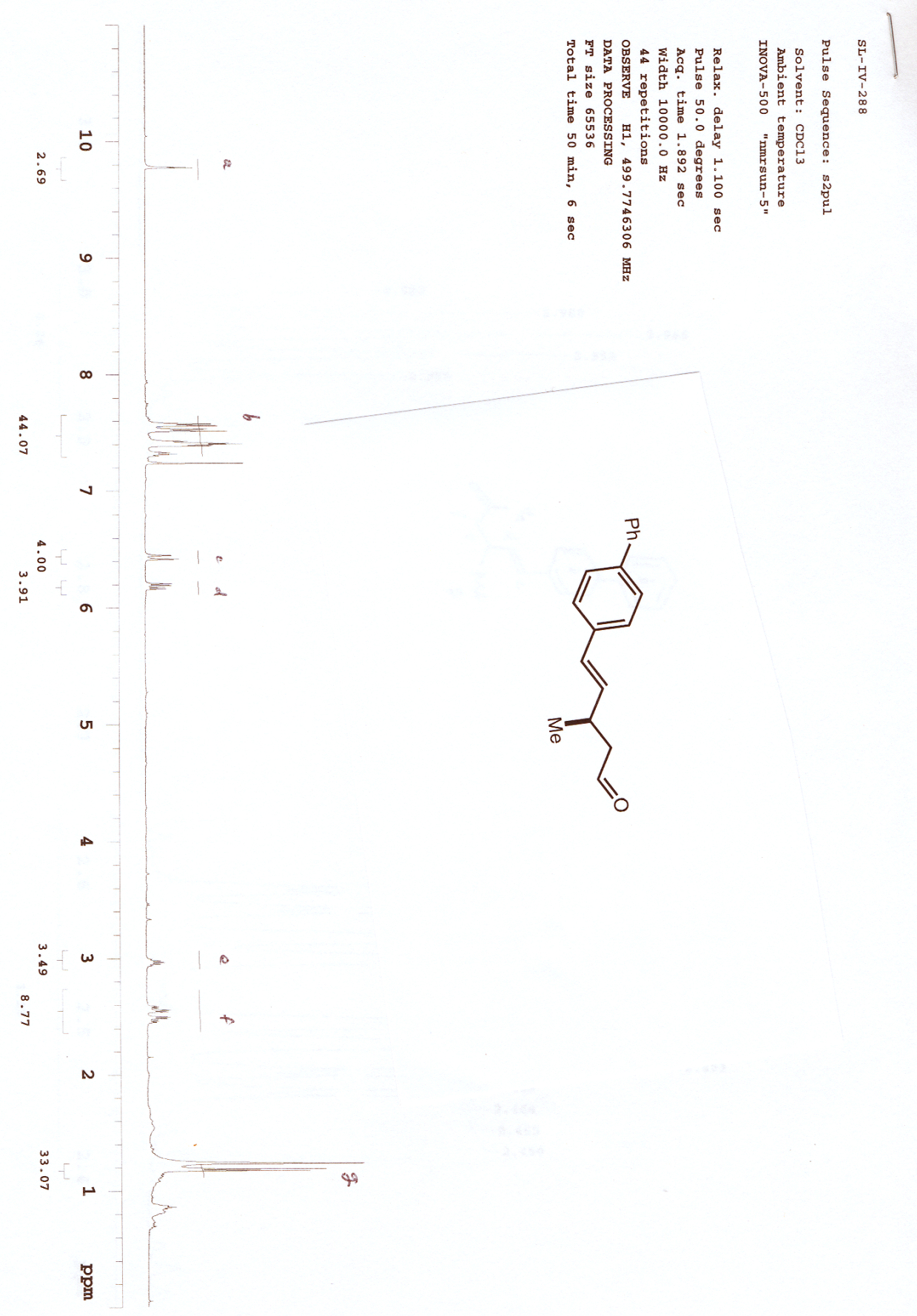




\section{BergerSFC Chromatogram Report}

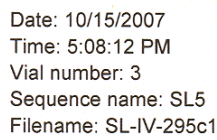

Sequence name: SL5

Filename: SL-IV-295c1

Method Name: ODH_IPA_5-35

User Name: SFC User

Acquisition Date: 2/1/2007 6:28:50 PM

Run Information:

NA

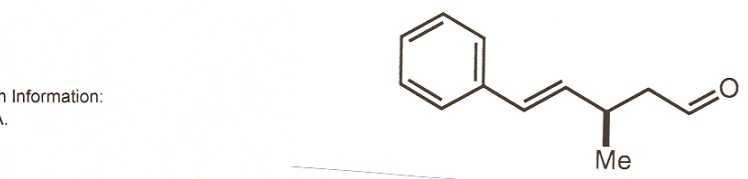

SL-IV-295c1:

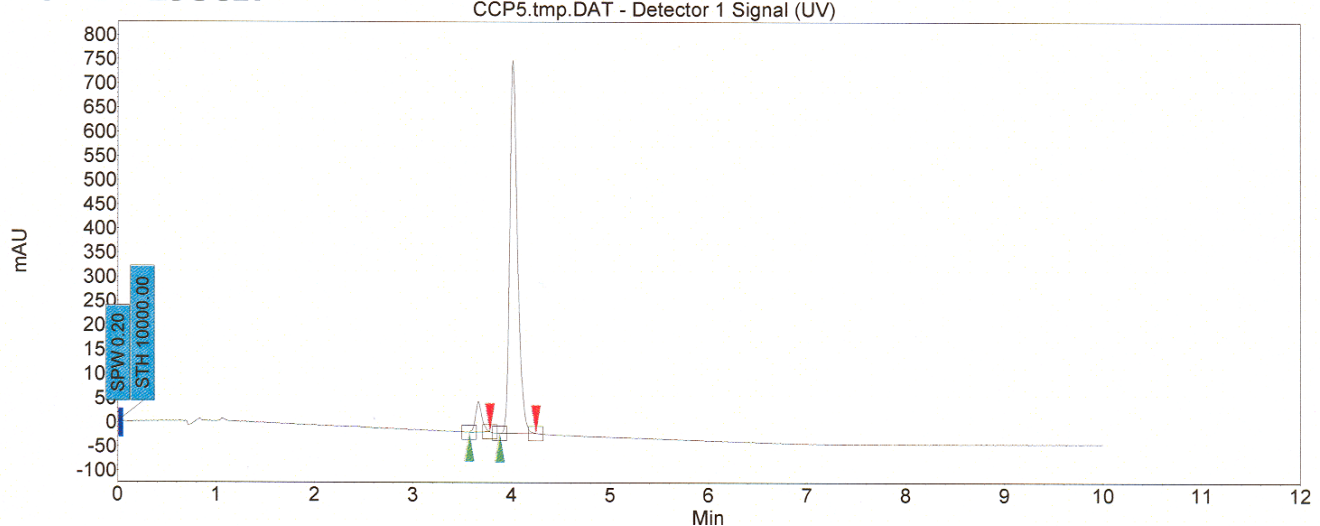

The Chromatogram Noise is 0

\section{Results Table:}

\begin{tabular}{|c|l|r|r|r|r|r|r|r|r|}
\hline Index & Name & Start & Time & End & RT Offset & Quantity & Heiaht & Area & Area \\
\hline \hline & & {$[$ Min] } & {$[$ Min] } & {$[$ Min] } & {$[$ Min] } & {$[\%$ Area] } & {$[\mu \mathrm{V}]$} & {$[\mu \mathrm{V}$. Min] } & {$[\%]$} \\
\hline 2 & UNKNOWN & 3.57 & 3.66 & 3.78 & 0.00 & 6.27 & 63.4 & 4.7 & 6.272 \\
\hline 1 & UNKNOWN & 3.88 & 4.01 & 4.24 & 0.00 & 93.73 & 770.6 & 70.2 & 93.728 \\
\hline & & & & & & & & & \\
\hline Total & & & & & & 100.00 & 834.0 & 74.9 & 100.000 \\
\hline
\end{tabular}




\section{BergerSFC Chromatogram Report}

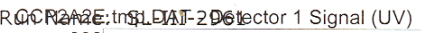

Run Tiną? 10.00

Injectiors

(1PA 5-25

Vial Numbaer. 2

Acquisition. 12:00:30 PM

sequence

$$
\text { है }
$$

है 10 डे
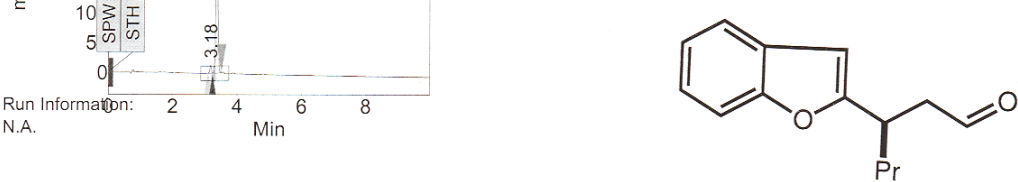

\section{SL-III-2961:}

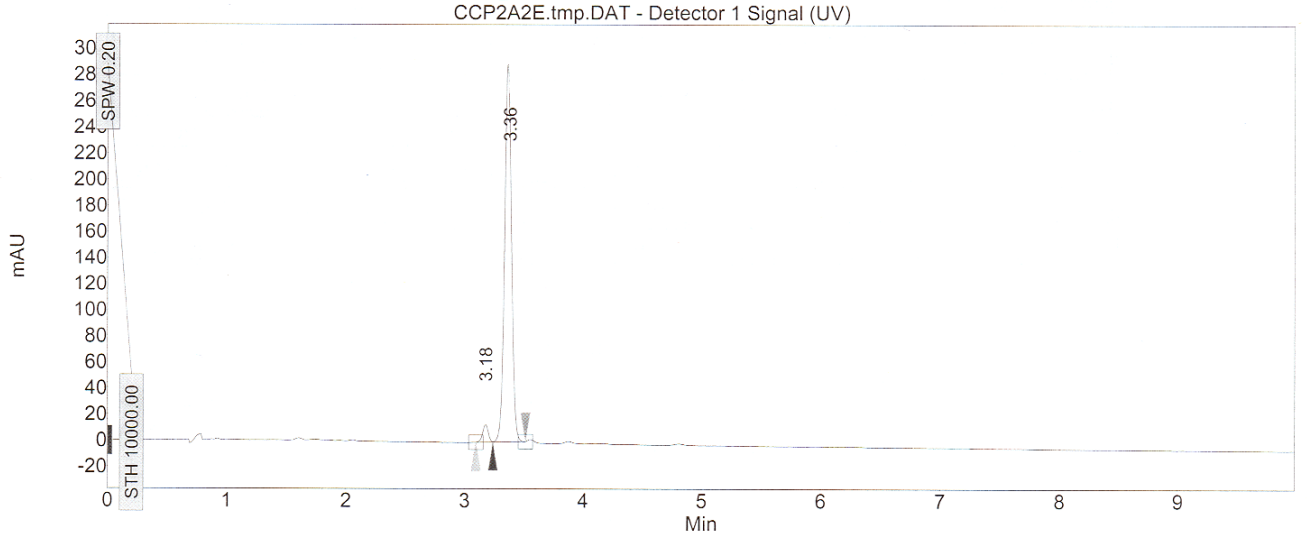

The Chromatogram Noise is 0

\section{Results Table:}

\begin{tabular}{|c|l|r|r|r|r|r|r|r|r|}
\hline Index & Name & Start & Time & End & RT Offset & Quantity & Height & Area & Area \\
\hline \hline & & {$[\mathrm{Min}]$} & {$[\mathrm{Min}]$} & {$[\mathrm{Min}]$} & {$[\mathrm{Min}]$} & {$[\%$ Area] } & {$[\mu \mathrm{V}]$} & {$[\mu \mathrm{V}$. Min] } & {$[\%]$} \\
\hline 1 & UNKNOWN & 3.10 & 3.18 & 3.24 & 0.00 & 3.60 & 13.4 & 0.7 & 3.604 \\
\hline 2 & UNKNOWN & 3.24 & 3.36 & 3.51 & 0.00 & 96.40 & 289.6 & 19.5 & 96.396 \\
\hline & & & & & & & & & \\
\hline Total & & & & & & 100.00 & 303.0 & 20.2 & 100.000 \\
\hline
\end{tabular}

$$
92.8 \%
$$




\section{BergerSFC Chromatogram Report}

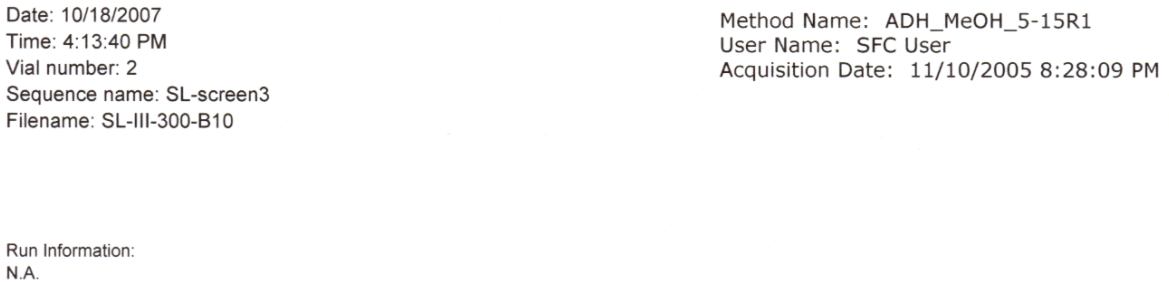

Method Name: ADH_MeOH_5-15R1

User Name: SFC User

Acquisition Date: 11/10/2005 8:28:09 PM

\section{SL-III-300-B 10:}

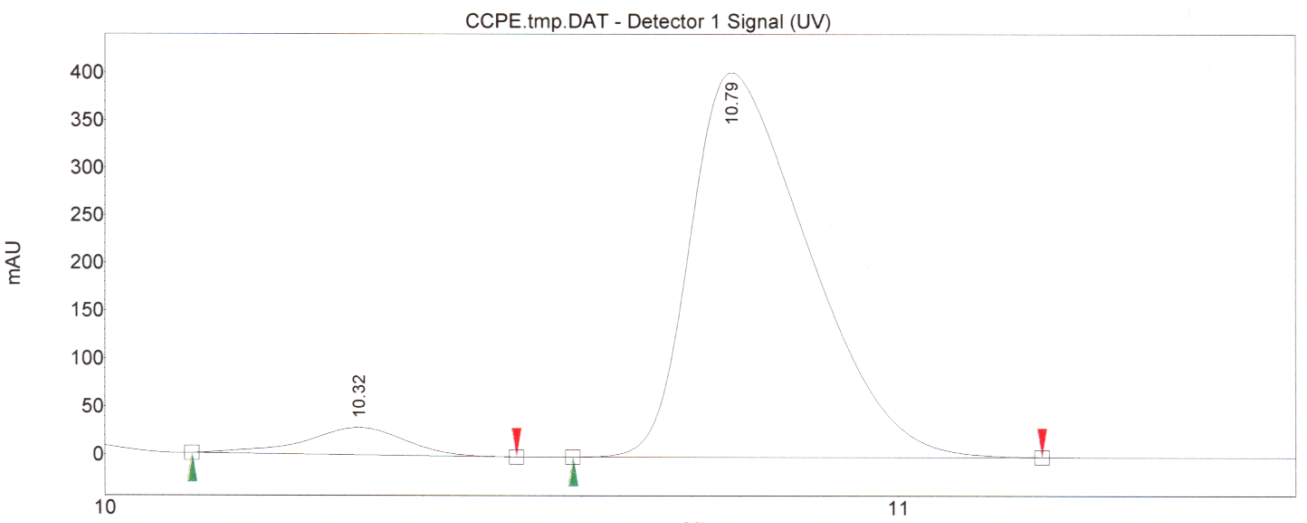

Min

The Chromatogram Noise is 0

\section{Results Table:}

\begin{tabular}{|c|l|r|r|r|r|r|}
\hline Index & Name & Time & Width USP & Height & Area & Area \\
\hline \hline & & {$[\mathrm{Min}]$} & {$[\mathrm{Min}]$} & {$[\mu \mathrm{V}]$} & {$[\mu \mathrm{V} . \mathrm{Min}]$} & {$[\%]$} \\
\hline 1 & UNKNOWN & 10.32 & 0.22 & 28.6 & 4.2 & 5.698 \\
\hline 2 & UNKNOWN & 10.79 & 0.28 & 403.2 & 69.2 & 94.302 \\
\hline & & & & & & \\
\hline Total & & & & 431.8 & 73.3 & 100.000 \\
\hline
\end{tabular}

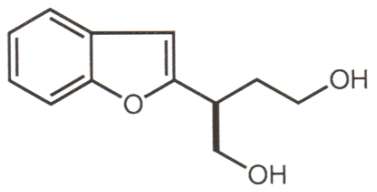


Date: $12 / 20 / 2005$

Time: 6:06:16 PM

Vial number: 1

Sequence name: SL-screen4

Filename: SL-IV-271

Run Information:

N.A.

SL-IV-271:

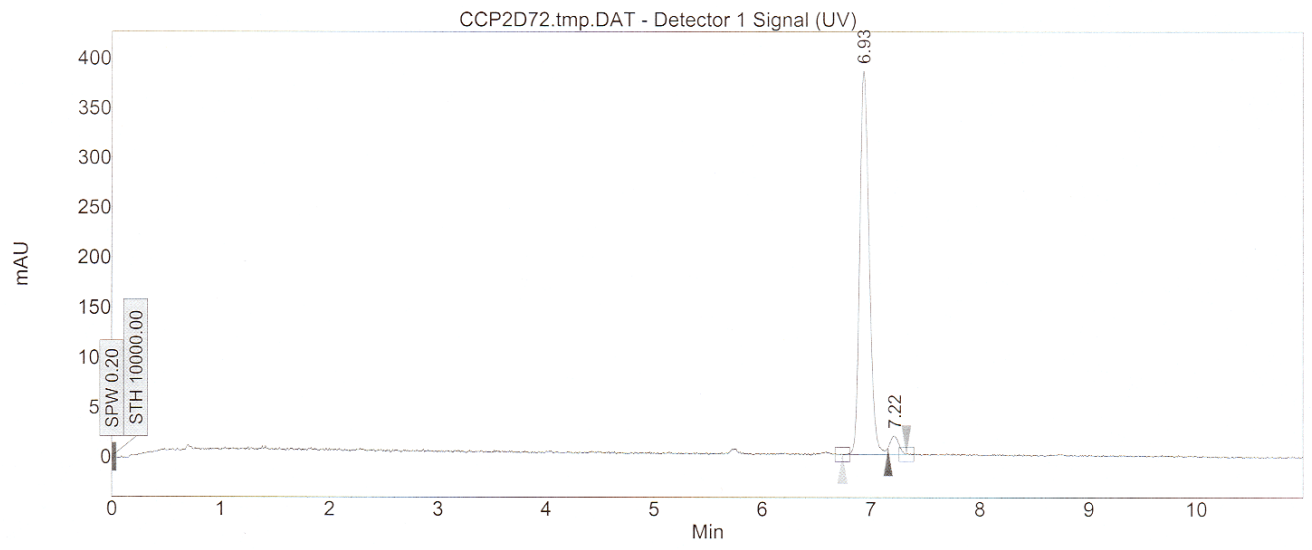

The Chromatogram Noise is 0

\section{Results Table:}

\begin{tabular}{|c|l|r|r|r|r|r|r|r|r|}
\hline Index & Name & Start & Time & End & RT Offset & Quantity & Height & Area & Area \\
\hline \hline & & {$[\mathrm{Min}]$} & {$[\mathrm{Min}]$} & {$[\mathrm{Min}]$} & {$[\mathrm{Min}]$} & {$[\%$ Area $]$} & {$[\mu \mathrm{V}]$} & {$[\mu \mathrm{V} . \mathrm{Min}]$} & {$[\%]$} \\
\hline 1 & UNKNOWN & 6.74 & 6.93 & 7.16 & 0.00 & 95.87 & 384.4 & 38.5 & 95.873 \\
\hline 2 & UNKNOWN & 7.16 & 7.22 & 7.33 & 0.00 & 4.13 & 18.5 & 1.7 & 4.127 \\
\hline & & & & & & & & & \\
\hline Total & & & & & & 100.00 & 402.9 & 40.2 & 100.000 \\
\hline
\end{tabular}

Mettls

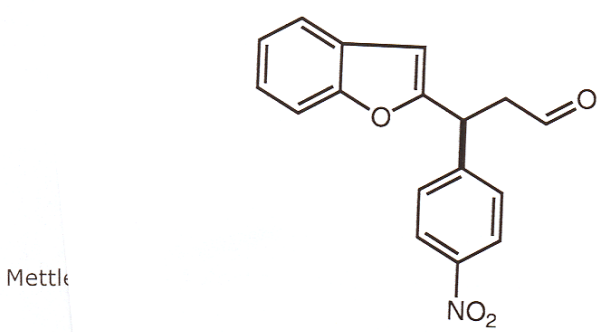

Method Name: ASH_MeOH_5-25

User Name: SFC User

Acquisition Date: 12/20/2005 5:53:14 PM
$91.7 \%$ er

Page 1 of 1 


\section{BergerSFC Chromatogram Report}

Date: $10 / 18 / 2007$

Time: 3:59:57 PM

Vial number: 2

Sequence name: SL-screen5

Filename: SL-IV-312

Run Information

SL-IV-312:
Method Name: ASH_MeOH_5-50

User Name: SFC User

Acquisition Date: 12/20/2005 6:05:38 PM

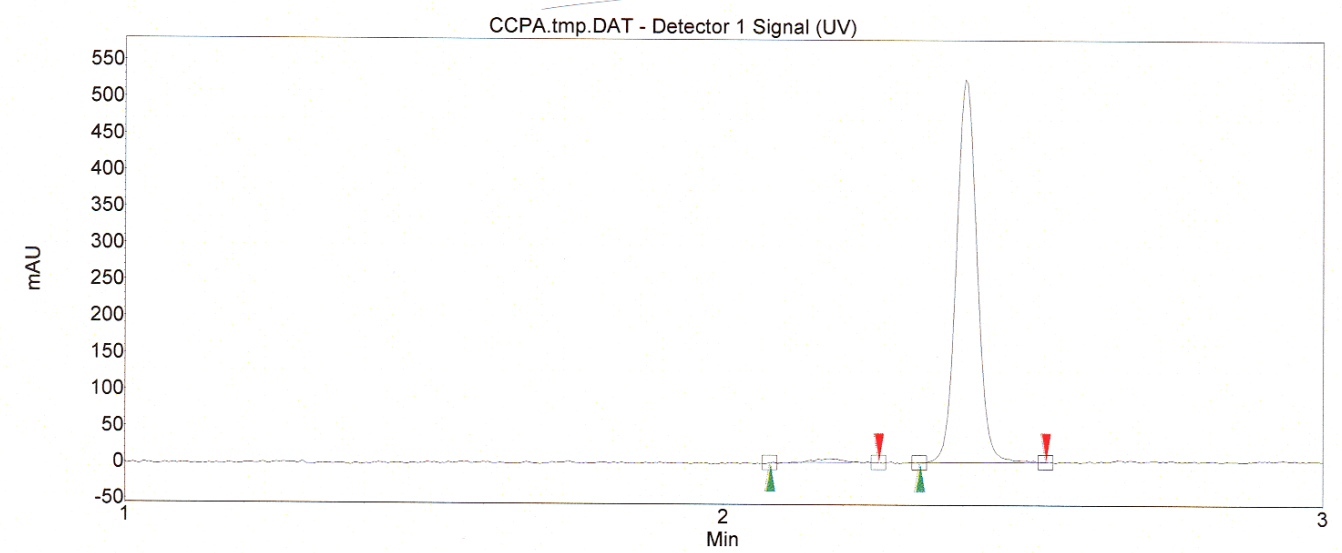

The Chromatogram Noise is 0

Results Table:

\begin{tabular}{|c|l|r|r|r|r|r|r|r|r|}
\hline Index & Name & Start & Time & End & RT Offset & Quantity & Height & Area & Area \\
\hline \hline & & {$[$ Min] } & {$[$ Min] } & {$[$ Min] } & {$[$ Min] } & {$[\%$ Area $]$} & {$[\mu \mathrm{V}]$} & {$[\mu \mathrm{HV}$. Min] } & {$[\%]$} \\
\hline 1 & UNKNOWN & 2.08 & 2.17 & 2.26 & 0.00 & 1.21 & 5.1 & 0.3 & 1.210 \\
\hline 2 & UNKNOWN & 2.33 & 2.40 & 2.54 & 0.00 & 98.79 & 524.1 & 21.0 & 98.790 \\
\hline & & & & & & & & & \\
\hline Total & & & & & & 100.00 & 529.1 & 21.3 & 100.000 \\
\hline
\end{tabular}




\section{BergerSFC Chromatogram Report}

Date: $2 / 22 / 2006$

Time: 11:09:53 AM

Vial number: 2

Sequence name: Nina4

Filename: SL-IV-943

Run Information:

N.A.

\section{SL-IV-943:}

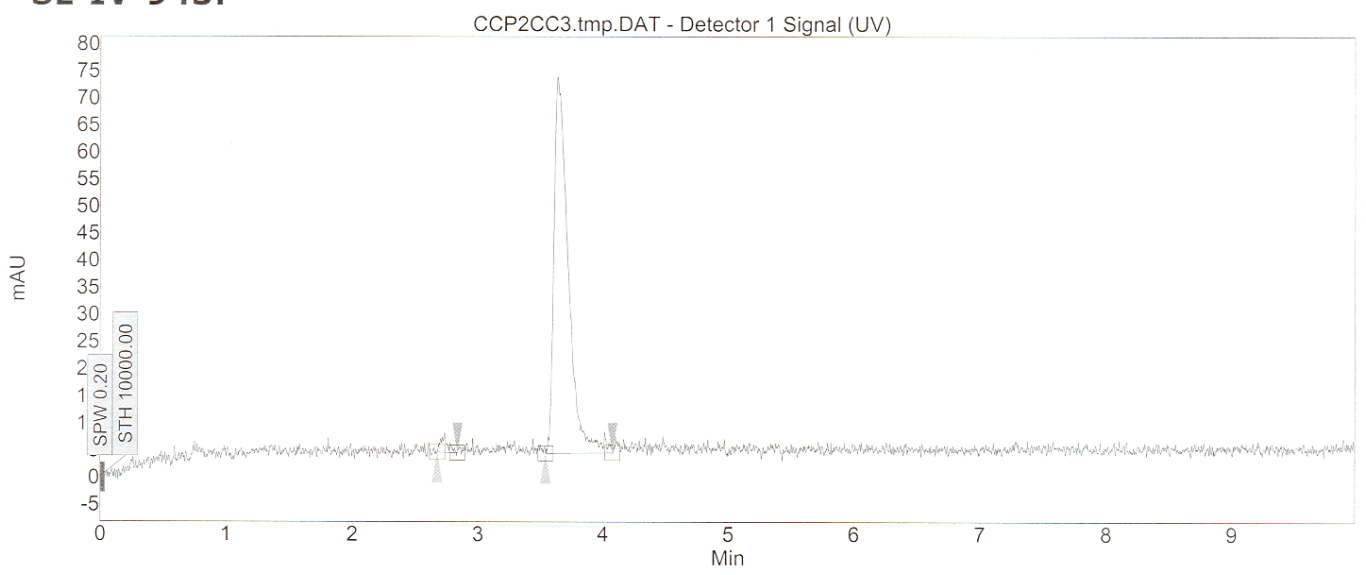

The Chromatogram Noise is 0

\section{Results Table:}

\begin{tabular}{|c|l|r|r|r|r|r|r|r|r|}
\hline Index & Name & Start & Time & End & RT Offset & Quantity & Height & Area & Area \\
\hline \hline & & {$[$ Min] } & {$[$ Min] } & {$[$ Min] } & {$[$ Min $]$} & {$[\%$ Area $]$} & {$[\mu \mathrm{V}]$} & {$[\mu \mathrm{V}$.Min $]$} & {$[\%]$} \\
\hline 2 & UNKNOWN & 2.68 & 2.73 & 2.84 & 0.00 & 2.26 & 2.9 & 0.2 & 2.261 \\
\hline 1 & UNKNOWN & 3.54 & 3.63 & 4.08 & 0.00 & 97.74 & 69.4 & 9.2 & 97.739 \\
\hline & & & & & & & & & \\
\hline Total & & & & & & 100.00 & 72.2 & 9.4 & 100.000 \\
\hline
\end{tabular}

$95.5 \%$ er
Method Name: ASH_MeCN_5-10

User Name: SFC User

Accuisition Date: 2/22/2006 10:54:02 AM

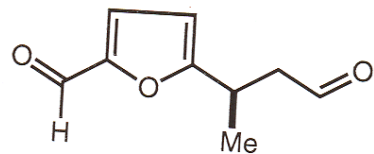




\section{BergerSFC Chromatogram Report}

Date: $10 / 18 / 2007$

Time: 4:12:58 PM

Vial number: 1

Sequence name: Nina2

Filename: SL-IV-971

Run Information:

NA.

\section{SL-IV-971:}

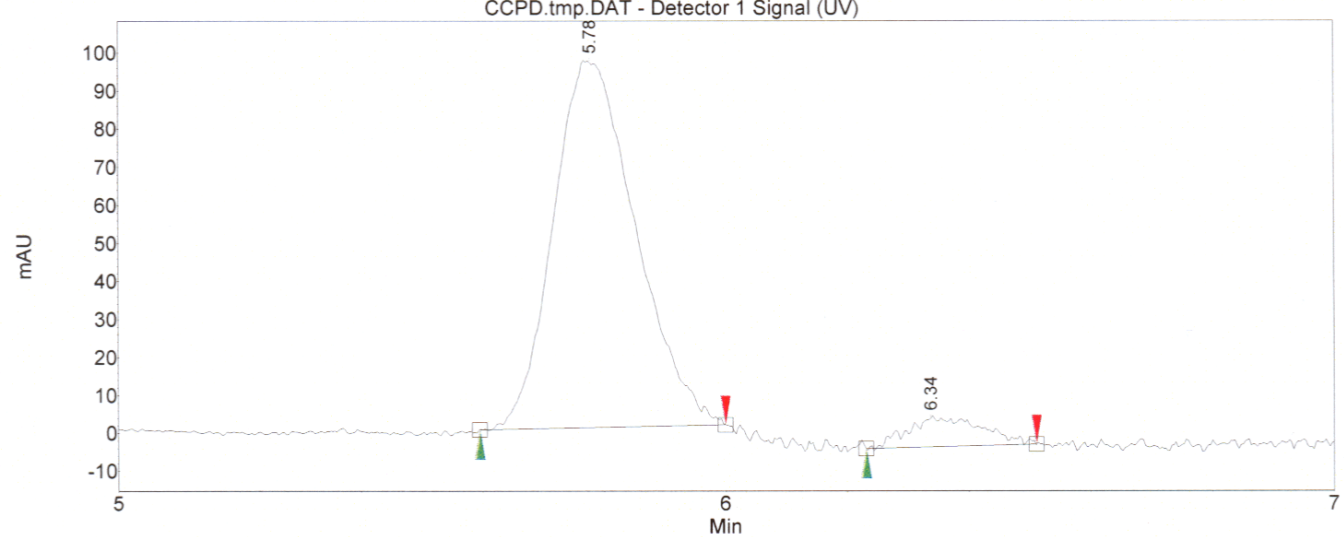

The Chromatogram Noise is 0

\section{Results Table:}

\begin{tabular}{|c|l|r|r|r|r|r|r|}
\hline Index & Name & Time & Width USP & Quantity & Height & Area & Area \\
\hline \hline & & {$[$ Min] } & {$[$ Min] } & {$[\%$ Area] } & {$[\mu \mathrm{V}]$} & {$[\mu \mathrm{V}$. Min] } & {$[\%]$} \\
\hline 1 & UNKNOWN & 5.78 & 0.25 & 93.21 & 96.0 & 15.2 & 93.209 \\
\hline 2 & UNKNOWN & 6.34 & 0.20 & 6.79 & 7.5 & 1.1 & 6.791 \\
\hline & & & & & & & \\
\hline Total & & & & 100.00 & 103.5 & 16.3 & 100.000 \\
\hline
\end{tabular}

Mettler Toledo Autochem 10/18/2007 4:12

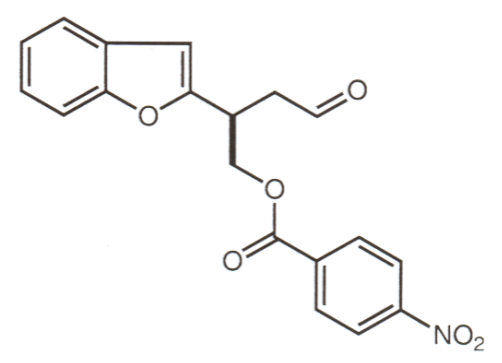

Name: SFC User

Acquisition Date: 2/23/2006 10:23:54 PM 


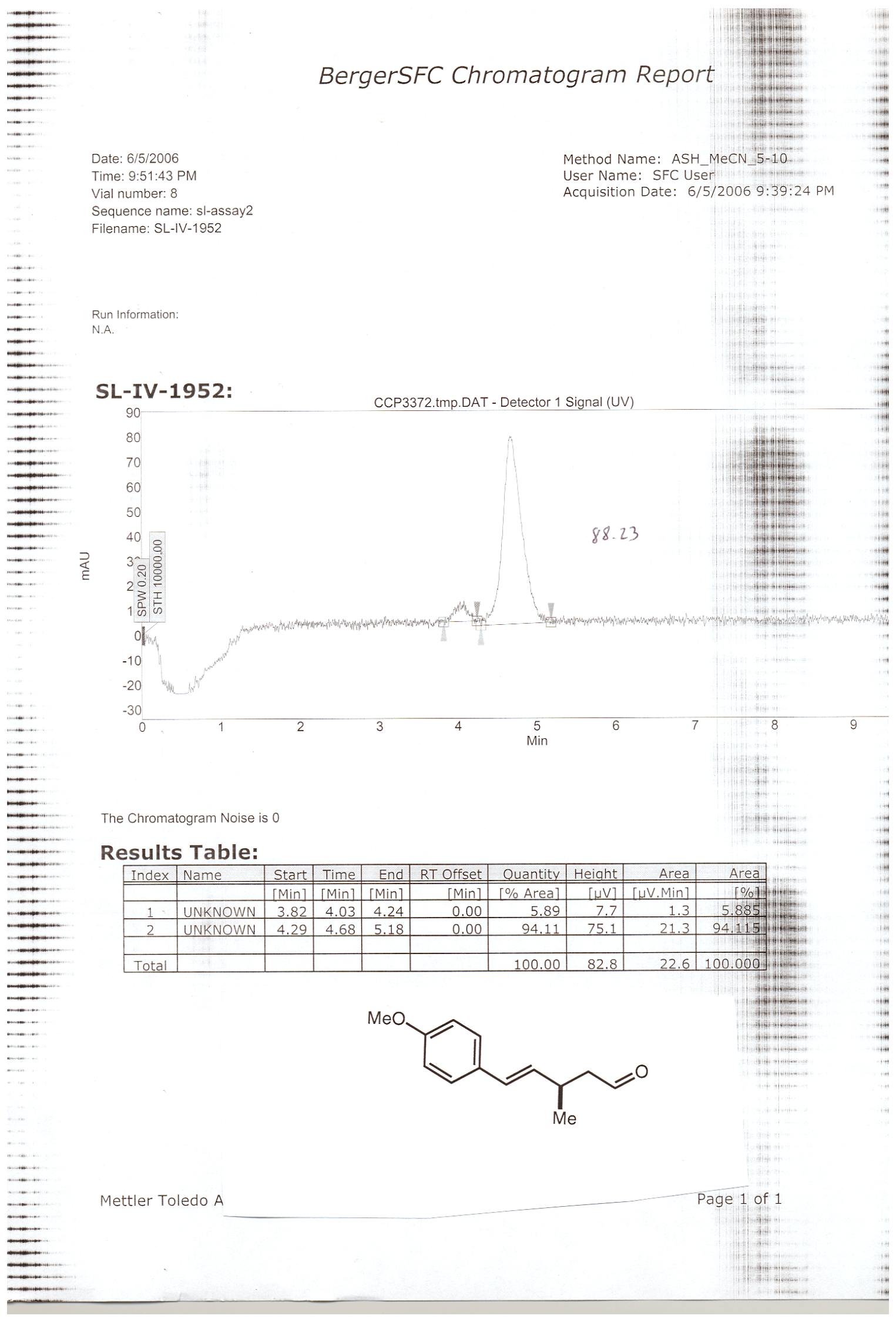




\section{BergerSFC Chromatogram Report}

Date: $10 / 18 / 2007$

Time: $3: 10: 53 \mathrm{PM}$

Vial number: 8

Sequence name: SL-1

Filename: SL-IV-28820

Run Information:

N.A.
Method Name: OJH_MeCN_5-15r2

User Name: SFC User

Acquisition Date: 1/22/2007 2:33:14 PM

SL-IV-28820:

700
650
600
550
500
450
400
350
300
250
200
150
100
50
0
-50
2

Ph

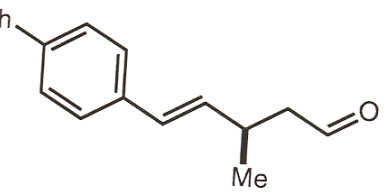
CCP186A.tmp.DAT - HP1100 DAD Signal A

00

600

550

450

400

300
250

200

150

100
50

0 (1)

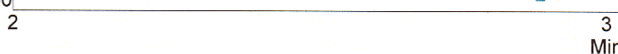

The Chromatogram Noise is 0

Results Table:

\begin{tabular}{|c|l|r|r|r|r|r|r|r|r|}
\hline Index & Name & Start & Time & End & RT Offset & Ouantity & Height & Area & Area \\
\hline \hline & & {$[$ Min] } & {$[$ Min] } & {$[$ Min] } & {$[$ Min] } & [\% Area] & {$[\mu \mathrm{V}]$} & {$[\mu \mathrm{V}$. Min] } & {$[\%]$} \\
\hline 1 & UNKNOWN & 2.89 & 2.96 & 3.04 & 0.00 & 3.20 & 34.8 & 2.0 & 3.203 \\
\hline 2 & UNKNOWN & 3.13 & 3.23 & 3.52 & 0.00 & 96.80 & 643.8 & 59.4 & 96.797 \\
\hline & & & & & & & & & \\
\hline Total & & & & & & 100.00 & 678.7 & 61.4 & 100.000 \\
\hline
\end{tabular}

